\title{
GEOHYDROLOGY OF TERTIARY ROCKS IN THE GREEN RIVER STRUCTURAL BASIN IN WYOMING, UTAH, AND COLORADO
}

by Lawrence J. Martin

\section{U.S. GEOLOGICAL SURVEY \\ Water-Resources Investigations Report 92-4164}

Prepared in cooperation with the WYOMING STATE ENGINEER 


\section{U.S. DEPARTMENT OF THE INTERIOR}

BRUCE BABBITT, Secretary

U.S. GEOLOGICAL SURVEY

Gordon P. Eaton, Director

The use of trade, product, industry, or firm names is for descriptive purposes only and does not imply endorsement by the U.S. Government.

For additional information write to:

\section{District Chief}

U.S. Geological Survey, WRD

2617 E. Lincolnway, Suite B

Cheyenne, Wyoming 82001-5662
Copies of this report can be purchased from:

U.S. Geological Survey

Branch of Information Services

Box 25286, Denver Federal Center

Denver, Colorado 80225 


\section{CONTENTS}

Abstract

Introduction

Purpose and scope

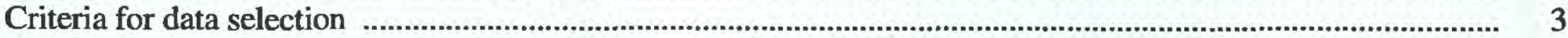

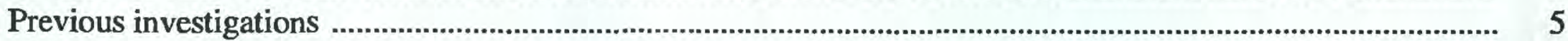

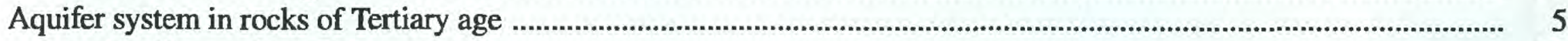

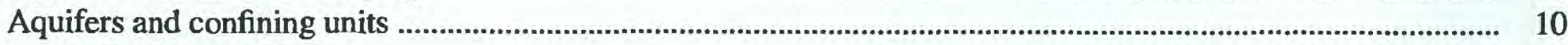

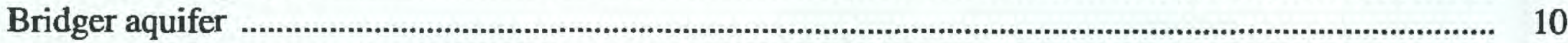

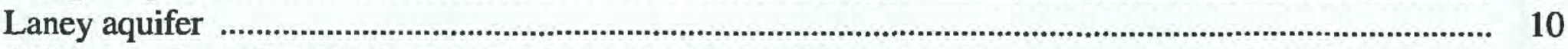

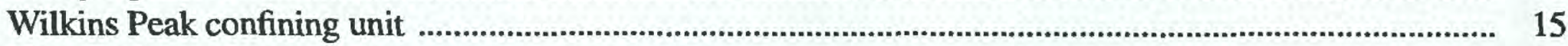

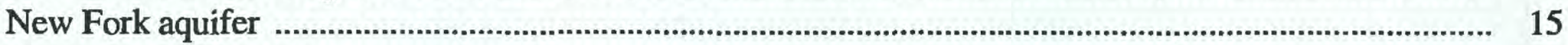

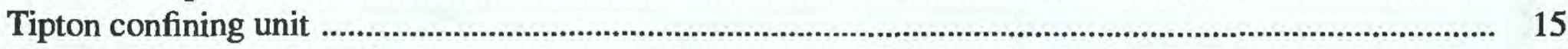

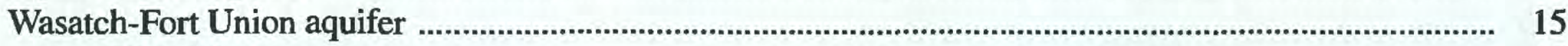

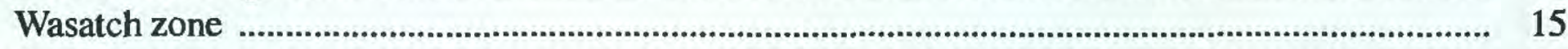

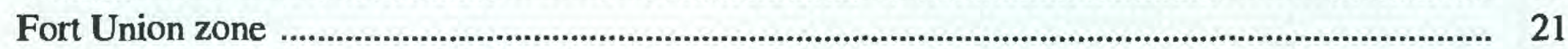

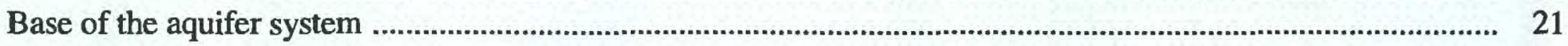

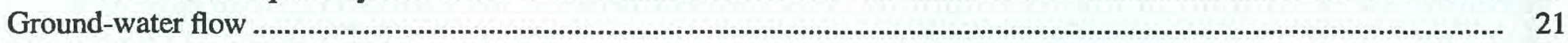

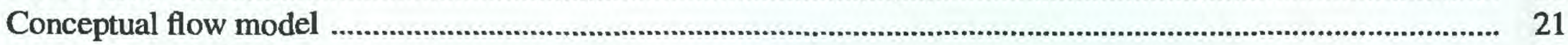

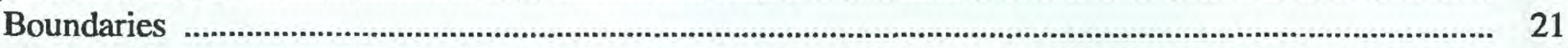

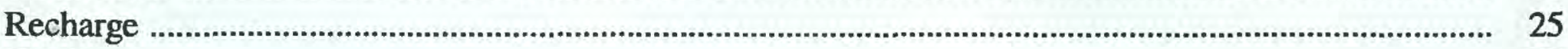

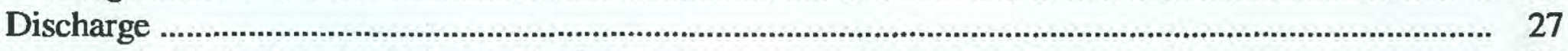

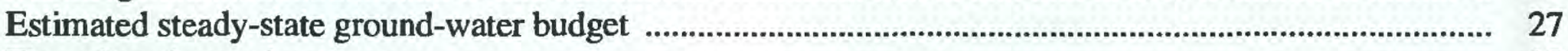

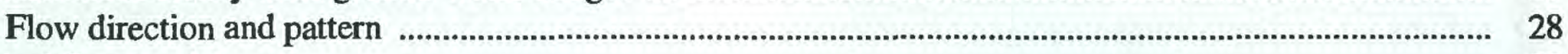

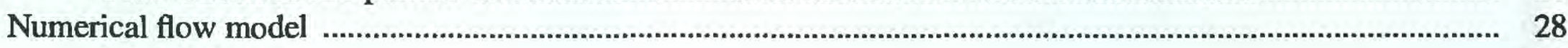

Model design ................................................................................................................................ 30

Finite-difference grid .......................................................................................................... 30

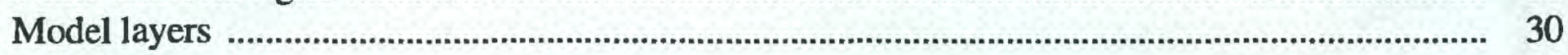

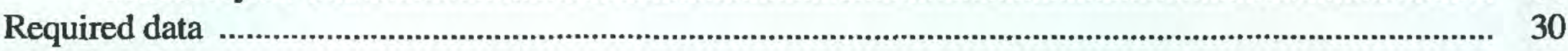

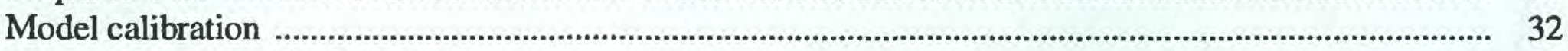

Stream-aquifer leakage ........................................................................................................ 32

Hydraulic heads ................................................................................................................... 34

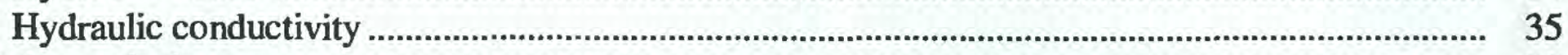

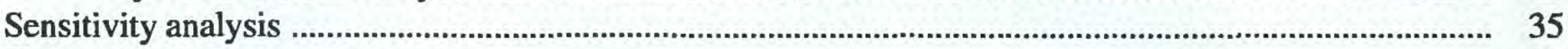

Use and limitations of the model ..................................................................................................... 39

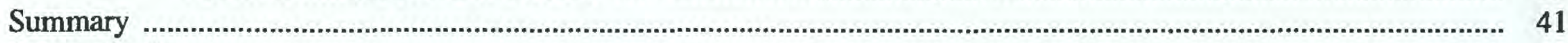

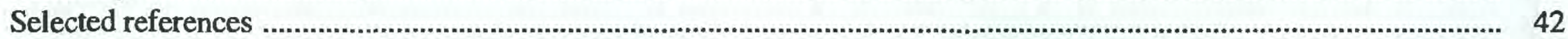


1. Map showing location of the Green River Structural Basin and study area in the Upper Colorado

River Basin.

2. Map showing tectonic features bounding the Green River Structural Basin.

3. Stratigraphic relation of the Tertiary rocks and geohydrologic units in the Green River Structural Basin ...

4. Generalized geologic units in Tertiary rocks

5. Generalized geologic section through the Green River Structural Basin

6-18. Maps showing:

6. Thickness of the Bridger aquifer in the Green River Structural Basin

7. Potentiometric surface (1985) of the Bridger aquifer in the Green River Structural Basin

8. Thickness of the Laney aquifer in the Green River Structural Basin

9. Potentiometric surface (1985) of the Laney aquifer in the Green River Structural Basin.

10. Thickness of the Wilkins Peak confining unit in the Green River Structural Basin.

11. Thickness of the New Fork aquifer in the Green River Structural Basin

12. Thickness of the Tipton confining unit in the Green River Structural Basin.

13. Thickness of the Wasatch zone of the Wasatch-Fort Union aquifer in the Green River Structural Basin.....

14. Potentiometric surface (1985) of the Wasatch zone of the Wasatch-Fort Union aquifer in the Green River Structural Basin

15. Thickness of the Fort Union zone of the Wasatch-Fort Union aquifer in the Green River Structural Basin.

16. Potentiometric surface (1985) of the Fort Union zone of the Wasatch-Fort Union aquifer in the Green River Structural Basin

17. Altitude and configuration of the base of Tertiary rocks in the Green River Structural Basin.

18. Estimated distribution of ground-water recharge in the Green River Structural Basin.

19. Diagrammatic geohydrologic section showing approximate directions of ground-water movement in the

Green River Structural Basin.

20-24. Maps showing:

20. Finite-difference grid showing river cells and the distribution of recharge to model layers in the Green River Structural Basin

21. Subdivisions of layers in the flow model and distribution of geohydrologic units in the model layers in the Green River Structural Basin . distributi of geo

22. Simulated potentiometric surface of layer 3 of the model, which includes the New Fork aquifer, in the Green River Structural Basin .

23. Areas of substantial simulated flow (greater than 0.1 cubic foot per second per model cell) between model layers.

24. Hydraulic conductivity of the calibrated ground-water flow model in the Green River Structural Basin ....

\section{TABLES}

1. Geohydrologic character of major geologic units

2. Estimated steady-state ground-water budget

3. Relation of model layers to geohydrologic units

4. Estimated and simulated stream-aquifer leakage

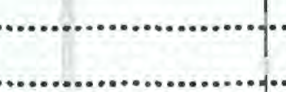

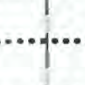

5. Root-mean-square deviation between final simula

ed heads and $/$ measured heads .

6. Root-mean-square deviation between final simulated heads and measured or interpolated heads..

7. Summary of hydraulic conductivity estimates from the ground-water flow model ...

8. Effects of changing the calibrated hydraulic conductivity on simulated hydraulic heads as indicated by the root-mean-square deviation

9. Effects of changing calibrated hydraulic conductivity on ground-water discharge to streams 
CONVERSION FACTORS AND VERTICAL DATUM

\begin{tabular}{|c|c|c|}
\hline Multiply & By & To obtain \\
\hline cubic foot per second $\left(\mathrm{ft}^{3} / \mathrm{s}\right)$ & 0.02832 & cubic meter per second \\
\hline foot per day $(\mathrm{ft} / \mathrm{d})$ & 0.3048 & meter per day \\
\hline gallon per minute (gal/min) & 0.06308 & liter per second \\
\hline inch (in.) & 25.4 & millimeter (mm) \\
\hline square mile $\left(\mathrm{mi}^{2}\right)$ & 2.590 & square kilometer \\
\hline
\end{tabular}

Sea level: In this report "sea level" refers to the National Geodetic Vertical Datum of 1929 (NGVD of 1929)--a geodetic datum derived from a general adjustment of the first-order level nets of both the United States and Canada, formerly called Sea Level Datum of 1929. 


\title{
GEOHYDROLOGY OF TERTIARY ROCKS IN THE GREEN RIVER STRUCTURAL BASIN IN WYOMING, UTAH, AND COLORADO
}

\author{
By Lawrence J. Martin
}

\section{ABSTRACT}

The ground-water system in rocks of Tertiary age in the Green River Structural Basin consists of four aquifers and two associated confining units. The Bridger aquifer is at land surface in the southern half of the basin. Fractures and solution channels in the Laney aquifer near the Big Sandy River have created an aquifer of limited basin extent. The New Fork Tongue of the Wasatch Formation is a sandstone aquifer located in the northern part of the basin between the Wilkins Peak and Tipton Shale Members of the Green River Formation--the two confining units. The main body of the Wasatch Formation represents a large potential water supply in the Green River Basin. Thick, permeable Wasatch sandstones are at or near land surface in most of the northern part of the basin. The Fort Union Formation consists of fluvial sandstones and shales that also represents a potential water supply in the Green River Basin. The Wasatch and Fort Union Formations have been designated the Wasatch and Fort Union zones of the Wasatch-Fort Union aquifer.

Inflow of water to the ground-water system includes infiltration of precipitation, streamflow, and excess irrigation water. Outflow occurs as ground-water discharge to streams. Pumping of ground water is not a significant source of discharge from the basin system. Recharge and discharge for the ground-water system in rocks of Tertiary age are estimated to be about 165 cubic feet per second.

A computer model was developed to simulate steady-state ground-water flow in the aquifers in Tertiary rocks of the Green River Basin. Basin geohydrologic characteristics of the aquifers and aquifer zones in Tertiary rocks are described by the calibrated flow model. Simulated hydraulic conductivity values were less than 18 feet per day, whereas the upper range of measured horizontal hydraulic conductivities equaled or exceeded 420 feet per day, except for the New Fork aquifer. Estimates of hydraulic conductivity from the calibrated flow model are within the range of values obtained from aquifer tests and drill-stem tests.

\section{INTRODUCTION}

The U.S. Geological Survey began a comprehensive study of ground water in the Upper Colorado River Basin in 1981, excluding the upper part of the San Juan Basin, in order to provide hydrologic information needed for effective development of ground-water resources. The study was part of the Regional Aquifer System Analysis (RASA) program. The purpose of the Upper Colorado River Basin study was to:

1. Classify stratigraphic sequences into intervals that constitute aquifers and confining units.

2. Map the areal extent of aquifers, aquifer thicknesses, and overburden thicknesses.

3. Describe hydrologic and geochemical characteristics of basin flow systems.

4. Quantitatively analyze basin flow systems under steady-state conditions.

The Upper Colorado River Basin includes the area drained by the Colorado River and its tributaries upstream from Lees Ferry, Arizona, and the Great Divide Basin, a closed basin in Wyoming. The study area for the RASA is about $99,000 \mathrm{mi}^{2}$ (square mile) in parts of Arizona, Colorauiv, Nvew Mexico, Utah, and Wyoming (fig. 1). It is characterized by high, rugged mountains, broad basins, and high plateaus that have been deeply entrenched and dissected by streams. 


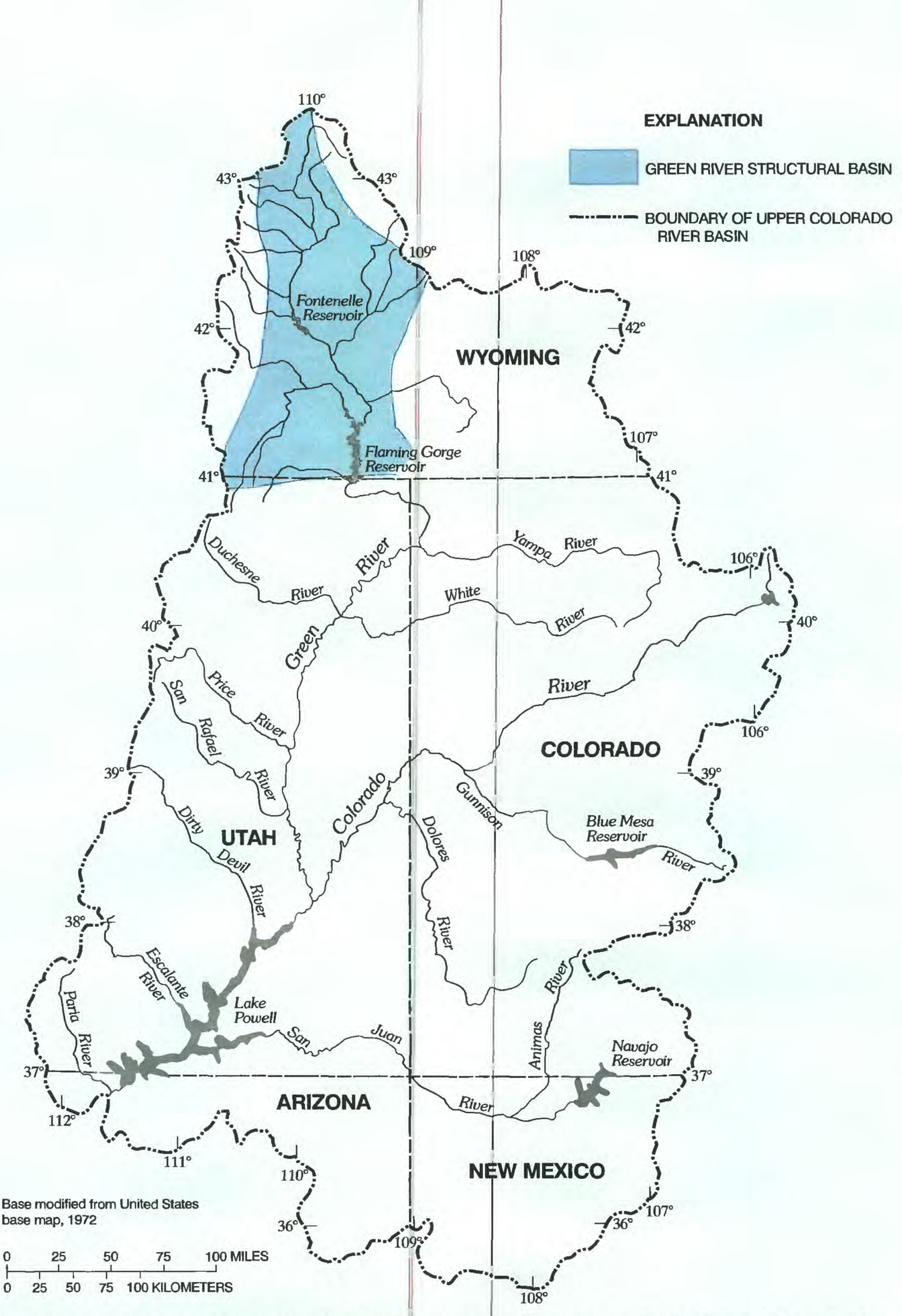

Figure 1. Location of the Green River Structural Basin and study area in the Upper Colorado River Basin. 
The major emphasis of the study of the Upper Colorado River Basin is on the consolidated sedimentary aquifers in rocks of Paleozoic, Mesozoic, and Cenozoic age. The emphasis of the study of Cenozoic aquifers is the Tertiary aquifers because Quaternary aquifers are important only locally (Taylor and others, 1986). Tertiary aquifers occur mainly in the northern part of the Upper Colorado River Basin. The Green River Structural Basin, which is part of the Green River drainage basin, is one of the major structural basins containing an aquifer system in rocks of Tertiary age. In this report, the Green River Structural Basin is referred to as the Green River Basin. This report describes that system of basin aquifers and confining units.

The study area for this report is the Green River Basin (Love, 1961) in southwestern Wyoming and small parts of northeastern Utah and northwestern Colorado. Major uplifts border the Green River Basin on all sides: The Overthrust Belt on the west, the Uinta Uplift on the south, the Rock Springs Uplift on the east, and the Wind River Uplift and the Gros Ventre Uplift on the north (fig. 2). The land surface ranges from about 6,000 to $7,500 \mathrm{ft}$ above sea level and is typified by treeless plains, mesas, and badlands.

\section{Purpose and Scope}

The purpose of this report is to describe groundwater flow systems in Tertiary rocks in the Green River Basin. Specific objectives are the identification and description of basin aquifers and confining units, preparation of a steady-state ground-water budget, estimation of effective basin values of hydraulic conductivity based on calibration of a steady-state ground-water flow model, and qualitative description of groundwater movement.

The emphasis of this study has been directed toward describing the basin-wide ground-water flow system. The basin ground-water flow system is defined as flow from recharge areas along the margins of the Green River Basin to discharge areas along the downstream reaches of the Green River and its main tributaries.

\section{Criteria for Data Selection}

The quantity, distribution, and quality of data available for geologic and hydrologic mapping generally differed for each geohydrologic unit. Generally, data were clustered in areas of intense development, such as hydrocarbon traps or local areas where large well yields are possible. Also, because information was obtained from a variety of sources, usually from sources with unknown quality-control procedures, it was important to evaluate the quality of the reported data.

Emphasis was placed on using only selected data to define the hydrologic system. The vast majority of geologic data, principally altitudes of formation tops, were obtained from the petroleum industry through the computerized files of Petroleum Information Corporation. The data were used to construct maps of formation thickness and a map showing the altitude and configuration of the base of Tertiary rocks. In using the geologic data, the author generally relied on the interpretation of formation tops from drill cuttings or geophysical well logs by petroleum geologists. These interpretations are considered to be accurate. The only quality-control checks on these data interpretations were for consistency among formation-top data for similar areas. When inconsistencies were noted, the complete geologic logs were reviewed; the more detailed logs were used in geologic mapping whereas vague or very general logs were ignored. Large quantities of geologic data were located at well fields where commercial quantities of hydrocarbons are produced. Because the occurrence of hydrocarbons generally is associated with structural or stratigraphic anomalies, data from these well fields were not considered to be reliable indicators of basin trends.

The hydraulic-head data used to construct potentiometric-surface maps were obtained from two sources: Ground-water-level measurements from computerized files of the U.S. Geological Survey, and drillstem-test measurements made by the petroleum industry. Drill-stem-test data were obtained from either Teller and Chafin (1986) or the computerized files of Petroleum Information Corporation. In no case were data used unless the stratigraphic interval of the hydraulic-head measurement was known and could be compared to existing geologic structure-contour maps. Water-level measurements generally were available in outcrop areas; drill-stem-test data were available in areas overlain by younger formations. In areas having several sources of data, water-level measurements were considered most reliable. Drill-stem-test data given by Teller and Chafin (1986) were considered the second most reliable because of the more complete quality-control checks possible. A complete discussion of quality-control checks possible with drill-stemtest data is provided by Teller and Chafin (1986). 


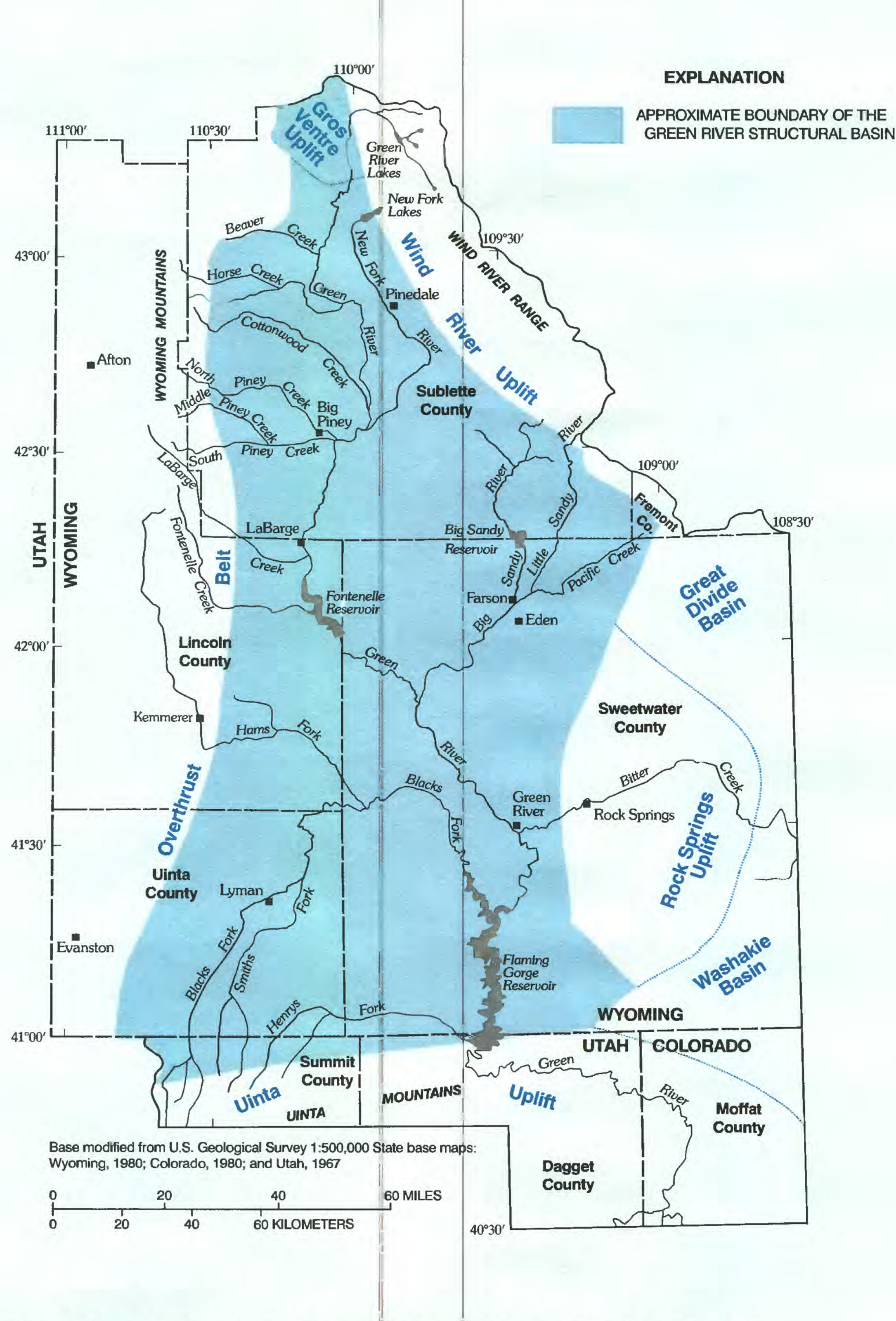

Flgure 2. Tectonic features bounding the Green River Structural Basin (modified from Love, 1961). 
Hydraulic-head data representing steady-state flow conditions were used in constructing potentiometric-surface maps. Data were reviewed in areas where changes in hydraulic head were suspected. Suspect areas included areas of irrigation pumpage, mine de-watering, and oil-field development. In cases where transient effects were observed, earliest hydraulic-head measurements were used. The only significant exception to this rule was in oil fields developed prior to 1950. Since 1950 , techniques for conducting drill-stem tests have improved significantly. Therefore, drillstem-test data from oil fields developed prior to 1950 were not used to construct potentiometric-surface maps.

\section{Previous Investigations}

Reports on previous geohydrologic studies of the Green River Basin include a reconnaissance report by Welder (1968), a basic ground-water data report (Zimmerman and Collier, 1985), and a report on the occurrence and use of ground water in the Green River Basin (Ahern and others, 1981). D.L. Naftz (U.S. Geological Survey, written commun., 1992) has investigated water-quality characteristics of the aquifers in Tertiary rocks in the Green River Basin as part of the RASA of the Upper Colorado River Basin.

Only a few detailed geohydrologic studies have been conducted in the Green River Basin. The results from a study in the Farson-Eden, Wyoming irrigation area by the U.S. Bureau of Reclamation (Barker and Sapik, 1965) include quantitative geohydrologic data. Robinove and Cummings (1963) discussed the geology and ground-water resources of $300 \mathrm{mi}^{2}$ in the vicinity of Lyman, Wyoming; Glover (1986) investigated an in situ oil-shale retort area near Rock Springs, Wyoming. Several reports contain only very general information; these include those by Gordon and others (1960), Dana (1962), and Lowham and others (1985).

\section{AQUIFER SYSTEM IN ROCKS OF TERTIARY AGE}

The areally extensive geohydrologic units that compose the aquifer system in the Tertiary rocks in the Green River Basin consist of four aquifers and two confining units. Aquifers, in descending order, have been designated the Bridger, Laney, New Fork, and Wasatch-Fort Union. Confining units are the Wilkins Peak and Tipton. The Bridger and Laney aquifers are separated from the New Fork and Wasatch-Fort Union aquifers by the confining units. The Wasatch-Fort Union aquifer is designated as a single aquifer; however, hydrologic properties of its two subunits (zones) seldom are similar at the same geographic location. Therefore, the Wasatch-Fort Union aquifer has been subdivided into the Wasatch zone and the Fort Union zone. The stratigraphic relation between Tertiary rocks and the aquifers and confining units in the Green River Basin is shown in figure 3.

Only the areally extensive Tertiary formations in the Green River Basin were considered major aquifers in this study. Some formations of minor areal extent are stratigraphically equivalent to a major geologic unit and considered part of a major aquifer: The Pass Peak Formation is included with the Wasatch zone of the Wasatch-Fort Union aquifer, the Hoback Formation is included with the Fort Union zone of the Wasatch-Fort Union aquifer. Similarly, many of the minor tongues and members of the Green River and Wasatch Formations are not discussed individually but are included in major aquifers or confining units (fig. 3 ). Investigation of local aquifers in the following geologic units was beyond the scope of this study: Quaternary alluvial deposits along major streams, Quaternary glacial deposits, Miocene and Oligocene rocks, the Browns Park Formation, the Bishop Conglomerate, and any other Oligocene and(or) Eocene rocks. These aquifers may be important local sources of ground water but are excluded from this study, except as noted.

The areal extent of major geologic formations, members, and tongues in the study area is shown in figure 4. Because of the basin approach to this study, the extent of the geohydrologic units was approximated by the contacts for the geologic units. The model, described later in this report, extends beyond the basin boundary in the Green River Formation along parts of the eastern boundary of the Green River Basin. Aquifers represented by these geologic units may not be saturated in some local areas. A generalized geologic section in figure 5 may be useful in understanding the stratigraphic relation of the geologic units, aquifers, and confining units in the Green River Basin. The geologic structure shown on the geologic section near the Uinta Mountains and the Wind River Range is simplified.

A brief summary of the hydrologic properties and published hydraulic-conductivity data for the major geologic units is listed in table 1. Published values of vertical hydraulic conductivity are not available for aquifers in Tertiaty rocks in the Green River Basin. Horizontal hydraulic conductivity values were obtained from aquifer tests, specific-capacity tests, drill-stem tests, and a numerical ground-water 


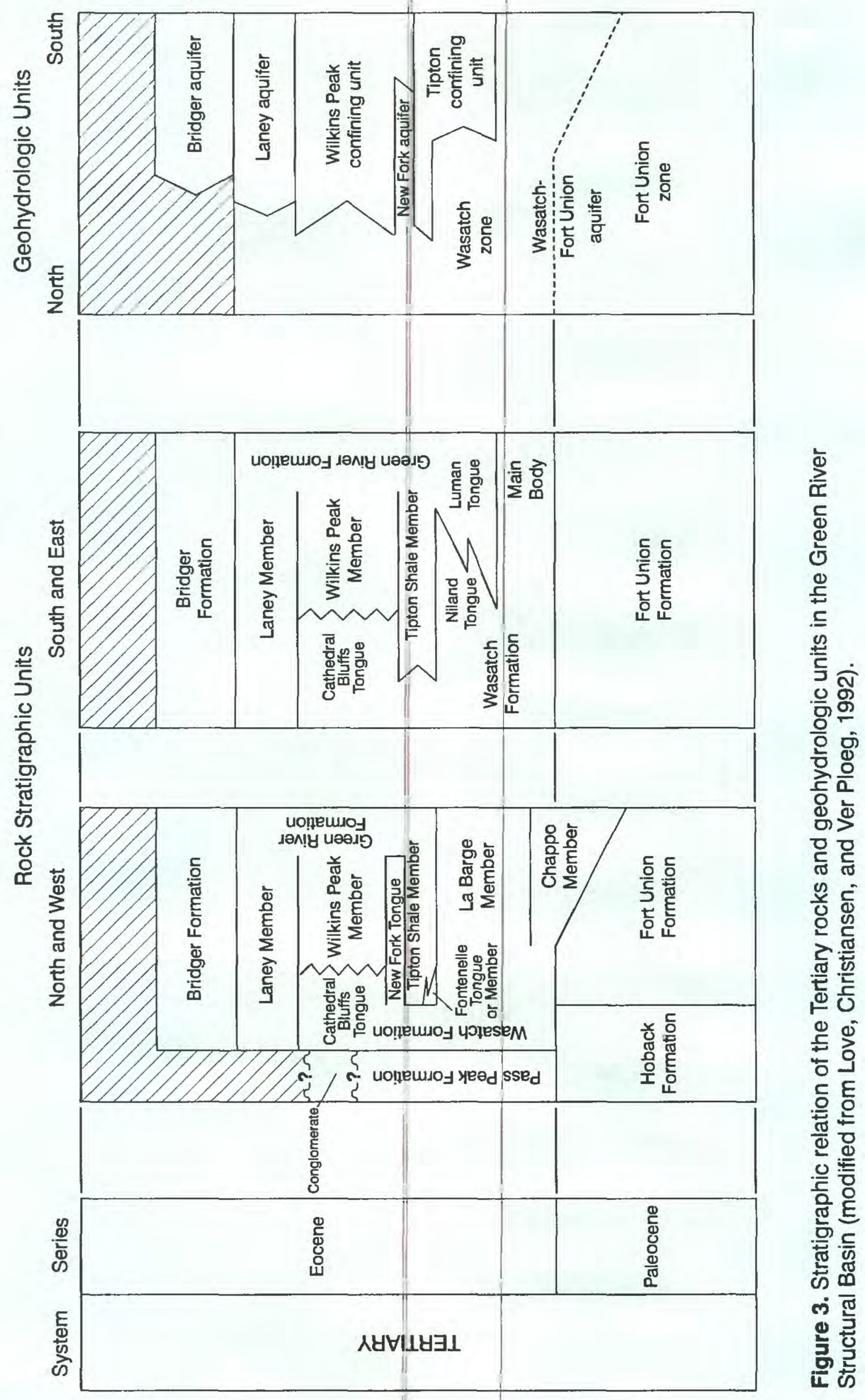




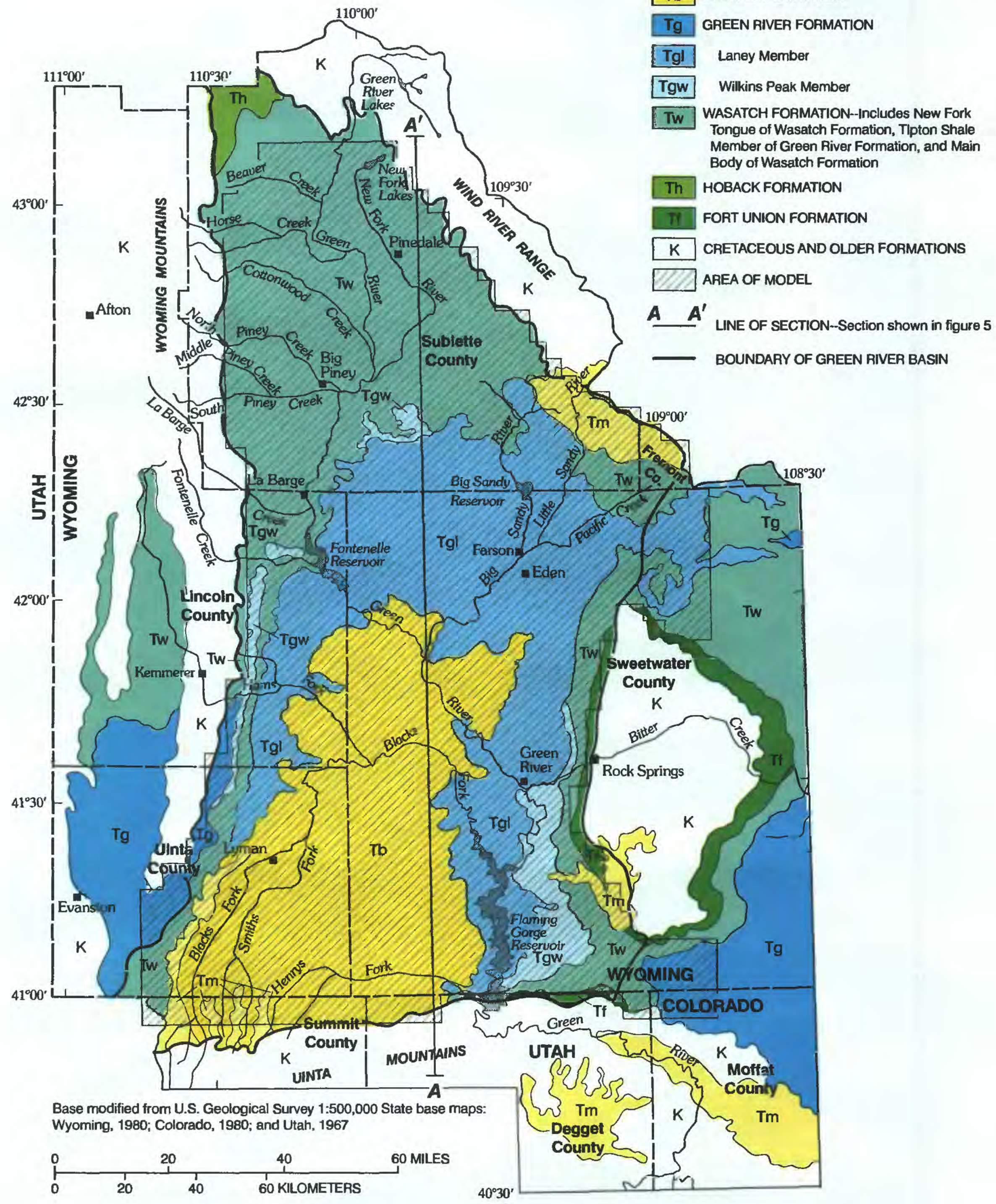

Tm MIOCENE AND OLIGOCENE FORMATIONS

Tb BRIDGER FORMATION

Tgw Wilkins Peak Member

Tw WASATCH FORMATION-Includes New Fork HOBACK FORMATION

FORT UNION FORMATION AREA OF MODEL

$A^{\prime}$ LINE OF SECTION-Section shown in figure 5 BOUNDARY OF GREEN RIVER BASIN 


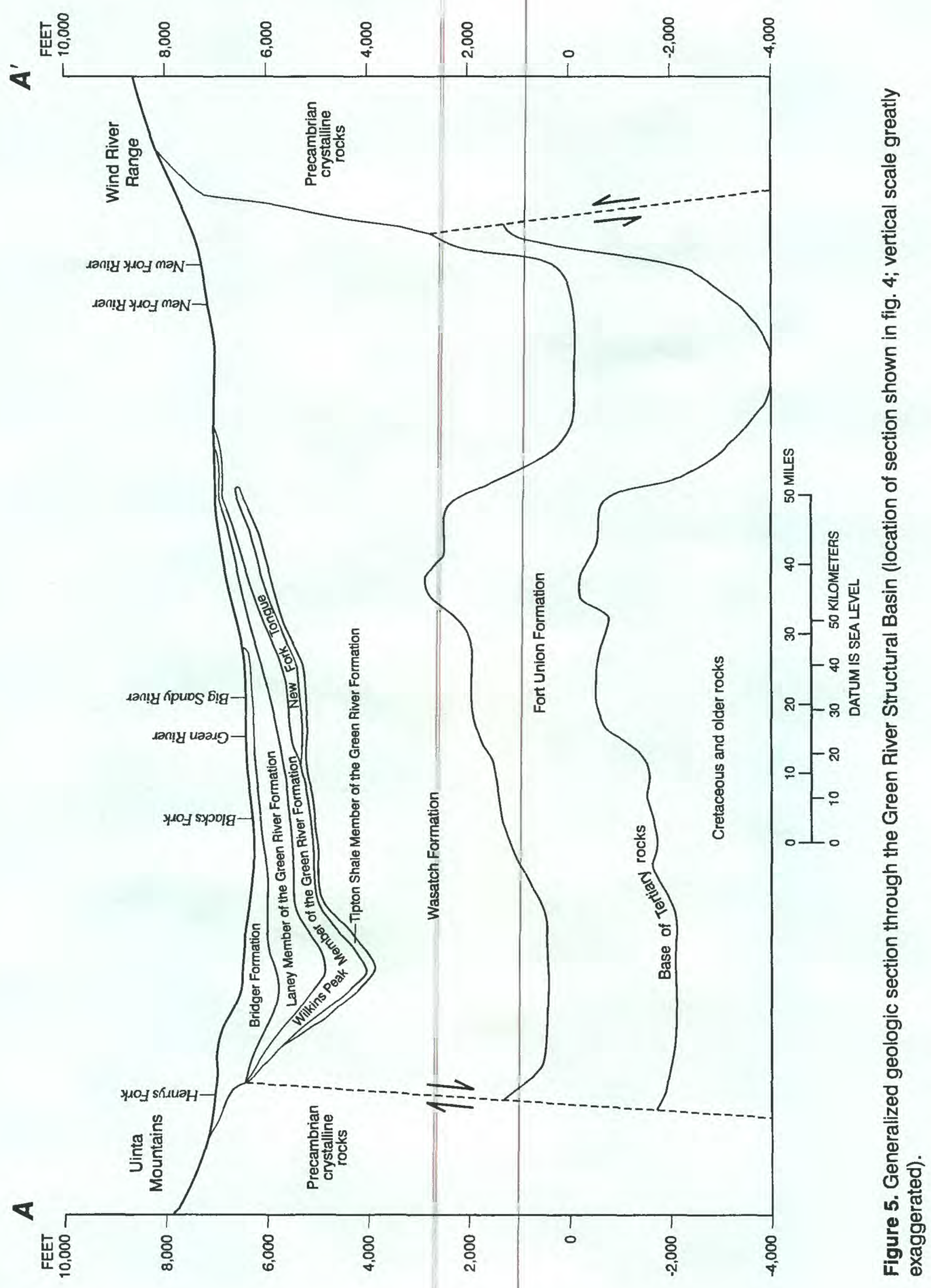


Table 1. Geohydrologic character of major geologic units (modified from work by K.C. Glover, B.A. Kimball, D.L. Naftz, and G.M. Clark, U.S. Geological Survey, written commun., 1986)

\begin{tabular}{|c|c|c|c|c|}
\hline \multirow[b]{2}{*}{ Tertiary formation } & \multirow[b]{2}{*}{ Hydrologlc propertles } & \multicolumn{3}{|c|}{ Horizontal hydraulic conductivity } \\
\hline & & $\begin{array}{l}\text { Number of } \\
\text { samples }\end{array}$ & $\begin{array}{c}\text { Range } \\
\text { (feet per day) }\end{array}$ & $\begin{array}{c}\text { Median } \\
\text { (feet per dey) }\end{array}$ \\
\hline Bridger Formation & $\begin{array}{l}\text { Yields less than } 50 \text { gallons per minute to wells. } \\
\text { Locally, however, large yields are possible } \\
\text { from sandstone strata. }\end{array}$ & 24 & $0.03-423$ & 11.0 \\
\hline $\begin{array}{l}\text { Laney Member of the } \\
\text { Green River } \\
\text { Formation }\end{array}$ & $\begin{array}{l}\text { Hydraulic conductivity is moderate to large } \\
\text { where fractures are present. Sandstone } \\
\text { predominates. Well yields are greatest near } \\
\text { the Big Sandy River. Elsewhere, hydraulic } \\
\text { conductivity and well yields are small. }\end{array}$ & 8 & $2.0-1,450$ & 13.0 \\
\hline $\begin{array}{l}\text { Wilkins Peak Member } \\
\text { of the Green River } \\
\text { Formation }\end{array}$ & $\begin{array}{l}\text { Member is relatively impermeable. Locally, } \\
\text { may yield less than } 30 \text { gallons per minute of } \\
\text { brine water to wells. }\end{array}$ & (1) & (1) & (1) \\
\hline $\begin{array}{l}\text { New Fork Tongue of the } \\
\text { Wasatch Formation }\end{array}$ & $\begin{array}{l}\text { The New Fork Tongue is the source of water } \\
\text { for numerous flowing wells near the Big } \\
\text { Sandy River. Hydraulic conductivity is } \\
\text { moderate, but large well yields are possible } \\
\text { where several hundred feet of saturated } \\
\text { thickness is penetrated. }\end{array}$ & 2 & $0.20-2.0$ & (1) \\
\hline $\begin{array}{l}\text { Tipton Shale Member of } \\
\text { the Green River } \\
\text { Formation }\end{array}$ & $\begin{array}{l}\text { Hydraulic conductivity is small. In the east- } \\
\text { central part of the Green River Basin the } \\
\text { sand content increases and differentiation } \\
\text { from the New Fork Tongue is difficult. In } \\
\text { that area, hydraulic conductivity is large. }\end{array}$ & (1) & ${ }^{2} 0.05-11$ & (1) \\
\hline Wasatch Formation & $\begin{array}{l}\text { Hydraulic-conductivity range indicates large } \\
\text { variations in the lithology of the formation. } \\
\text { Vertical differences in hydraulic head occur } \\
\text { within the Wasatch Formation in some areas. } \\
\text { Flow is confined where the Wasatch } \\
\text { Formation is overlain by the Green River } \\
\text { Formation. }\end{array}$ & 186 & $0.03-2,106$ & 8.7 \\
\hline Fort Union Formation & $\begin{array}{l}\text { Hydraulic conductivity is large in outcrop } \\
\text { areas. Where the formation is deeply buried } \\
\text { or where shale is present, hydraulic } \\
\text { conductivity is small. }\end{array}$ & 61 & $0.02-1,134$ & 40.0 \\
\hline
\end{tabular}

'No information is available.

${ }^{2}$ Glover, 1986 
flow model. The hydraulic conductivity values reported from the various tests are considered point values when viewed on a basin basis. These point values of hydraulic conductivity often do not correlate spatially and may not be useful indicators of basin ground-water movement. The lack of spatial correlation among estimates of hydraulic conductivity may be a result of the lenticular nature of sandstone bodies in the Wasatch-Fort Union aquifer and the variations in size and spacing of fractures in the Bridger and Laney aquifers. The use of drill-stem test data in estimating basin hydraulic conductivity may reflect a bias toward strata that can act as traps for oil and gas.

Members of the Green River Formation are predominantly fine-grained lacustrine deposits. In general, the underlying Wasatch and Fort Union

Formations consist of fluvial deposits. However, there is significant intertonguing of the Green River and Wasatch Formations. This intertonguing correlates with changes in the size of Eocene lakes, in which sediments that would become the Green River Formation were being deposited. Bradley (1964) describes the Green River Formation as a lens of fine-grained sedimentary rock embedded in a thick body of sandy mudstone that fills a large intermontane basin. The body of sandy mudstone is the Bridger Formation above the Green River Formation and the Wasatch Formation below the Green River Formation.

\section{Aquifers and Confining Units}

\section{Bridger Aquifer}

Fractured sandstone, tuff, and shale of the Bridger Formation compose the Bridger aquifer. The Bridger aquifer, in the southern part of the Green River Basin, generally is less than $1,000 \mathrm{ft}$ thick in the central part (fig. 6), but thickens to more than $1,500 \mathrm{ft}$ in the southernmost part.

The hydraulic heads used to construct the potentiometric surface of the Bridger aquifer (fig. 7) were compiled from water-level measurements in wells completed in the Bridger Formation. However, wells in the southwestern part of the basin typically are completed in both the overlying alluvium or glacial deposits and the Bridger Formation. These wells were used only where better control points were not available. Hydraulic-head data used to map the potentiometric surface of the Bridger aquifer are highly variable, indicating that local recharge and discharge are common and that vertical hydraulic gradients exist within the aquifer. Local flow systems in discontinuous, overly- ing aquifers in Quaternary rocks in the southwestern part of the basin probably affect water levels in the Bridger aquifer.

\section{Laney Aquifer}

The Laney Member of the Green River Formation is classified as an aquifer for purposes of this report. However, available data indicate the hydraulic conductivity of the Laney Member varies from large values in the northern part of the basin to small values similar to those of a confining unit in the southern part of the basin. In the northern part of the basin near the Big Sandy River, fractures and solution channels in the aquifer have enhanced its hydraulic conductivity. No evidence of fracture-enhanced hydraulic conductivity is available where the Laney Member is buried by the Bridger Formation or where it is at land surface in the southern part of the basin. Large values of hydraulic conductivity may occur in the Laney aquifer along the Uinta Mbuntains where a large percentage of conglomerate and other permeable rocks compose the aquifer. The thickness of the Laney Member exceeds $1,000 \mathrm{ft}$ in the south-central part of the Green River Basin; elsewhere thickness typically is 100 to $600 \mathrm{ft}$ (fig. 8).

The potentiometric surface of the Laney aquifer (fig. 9) was compiled primarily from water-level measurements in wells. Data for the potentiometric surface were available primarily in areas where the aquifer is at or near land surface--a good indication of the extent of that part of the aquifer with hydraulic conductivity sufficient to deliver usable quantities of water to wells.

The Laney aquifer intertongues with and has a gradational contact with the Wasatch zone of the Wasatch-Fort Union aquifer in the northern part of the basin. Water flowing south in the Wasatch zone moves into the Laney aquifer across this contact. Potentiometric-surface maps representing water-table conditions in the Wasatch zone of the Wasatch-Fort Union aquifer and Laney aquifer are continuous across the contact, indicating that flow is not impeded by the hydraulic characteristics of the Laney in the area of the contact.

\section{Wilkins Peak Confining Unit}

The Wilkins Peak Member of the Green River Formation together with the southern part of the Laney Member of the Green River Formation compose the Wilkins Peak confining unit. The Wilkins Peak confining unit, absent in the northern part of the Green River Basin, separates the Laney aquifer from the New Fork aquifer in the central part of the basin. Bedded trona 


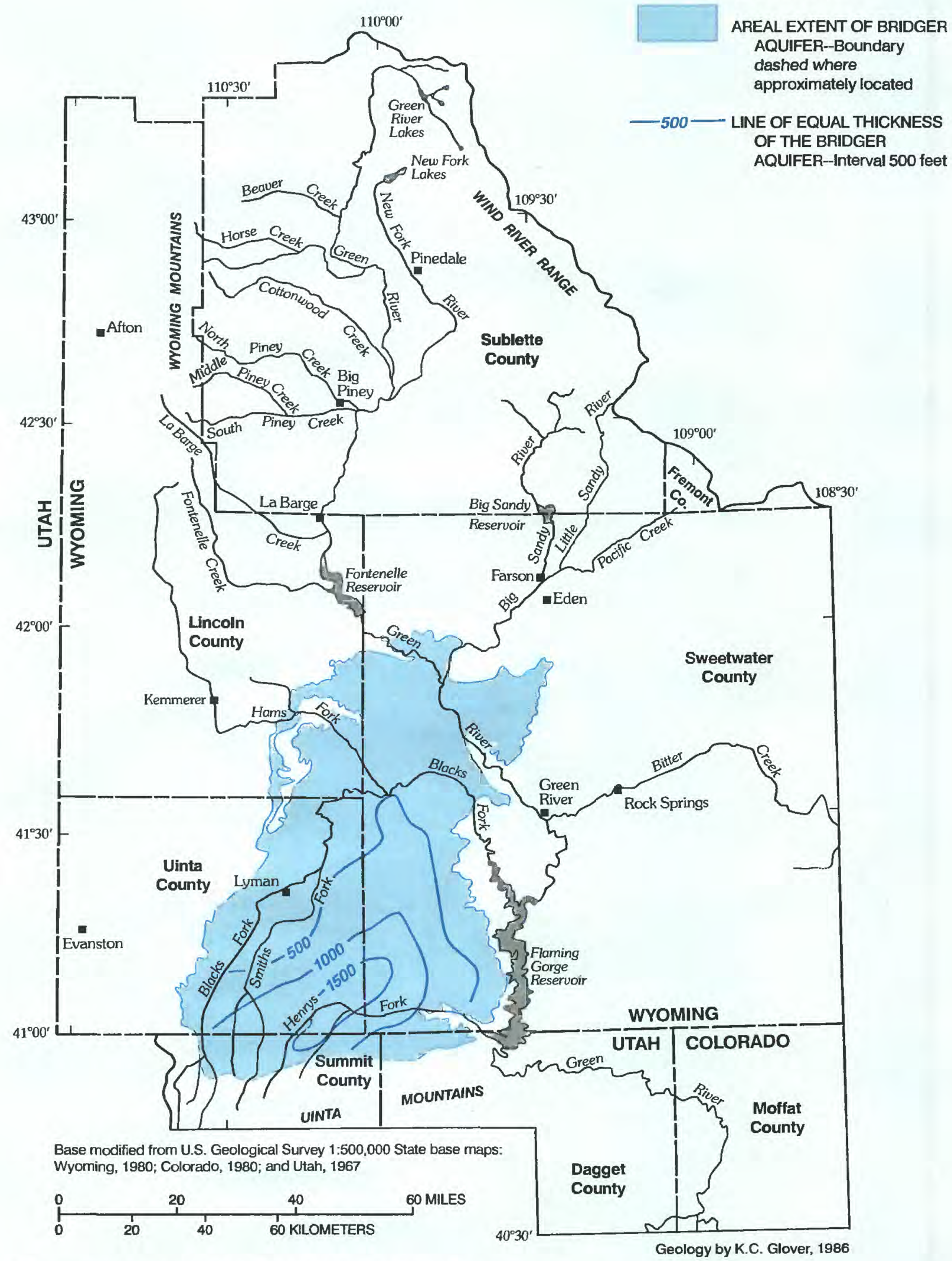

Figure 6. Thickness of the Bridger aquifer in the Green River Structural Basin. 


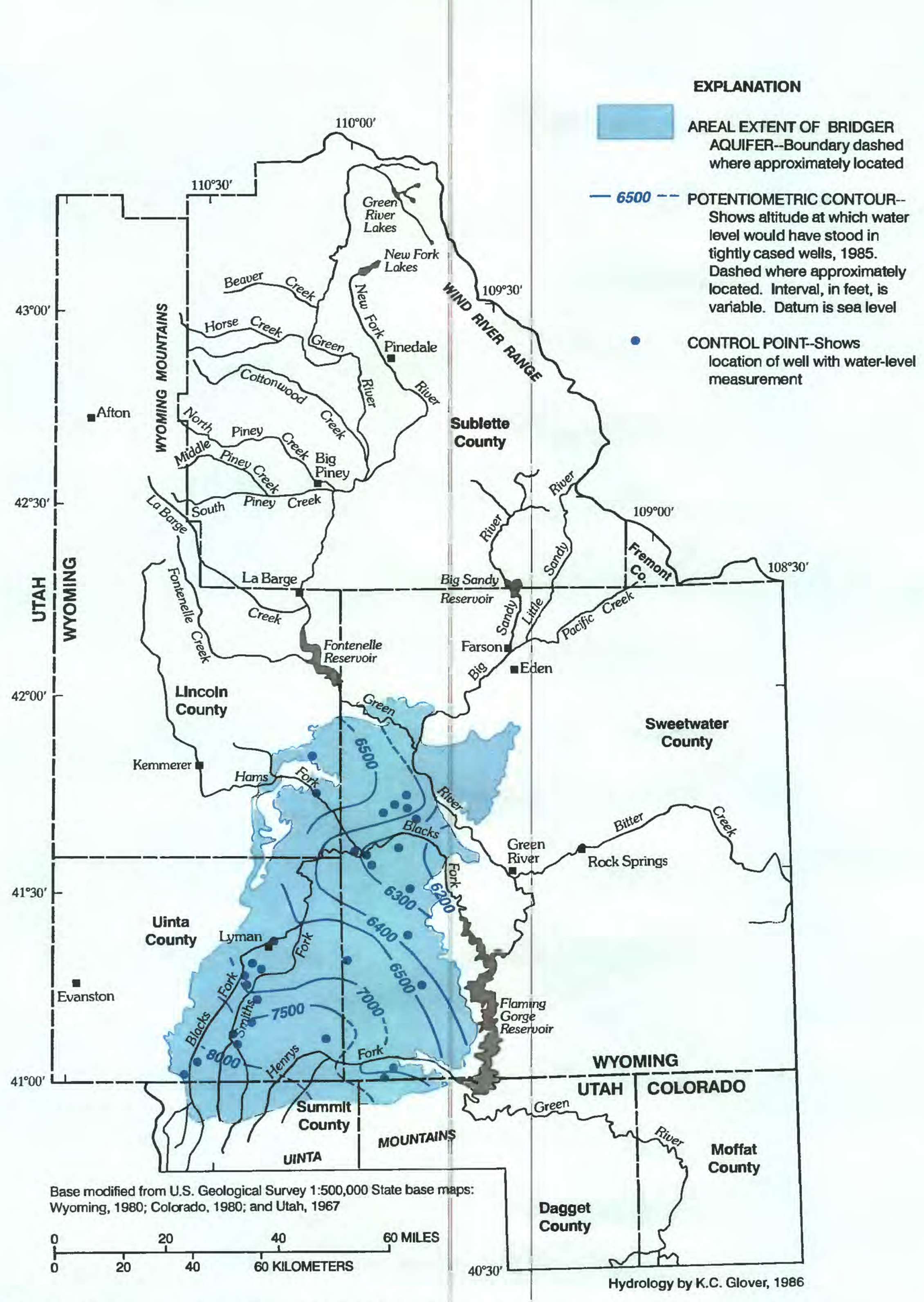

Figure 7. Potentiometric surface (1985) of the Bridger aquifer in the Green River Structural Basin. 
EXPLANATION

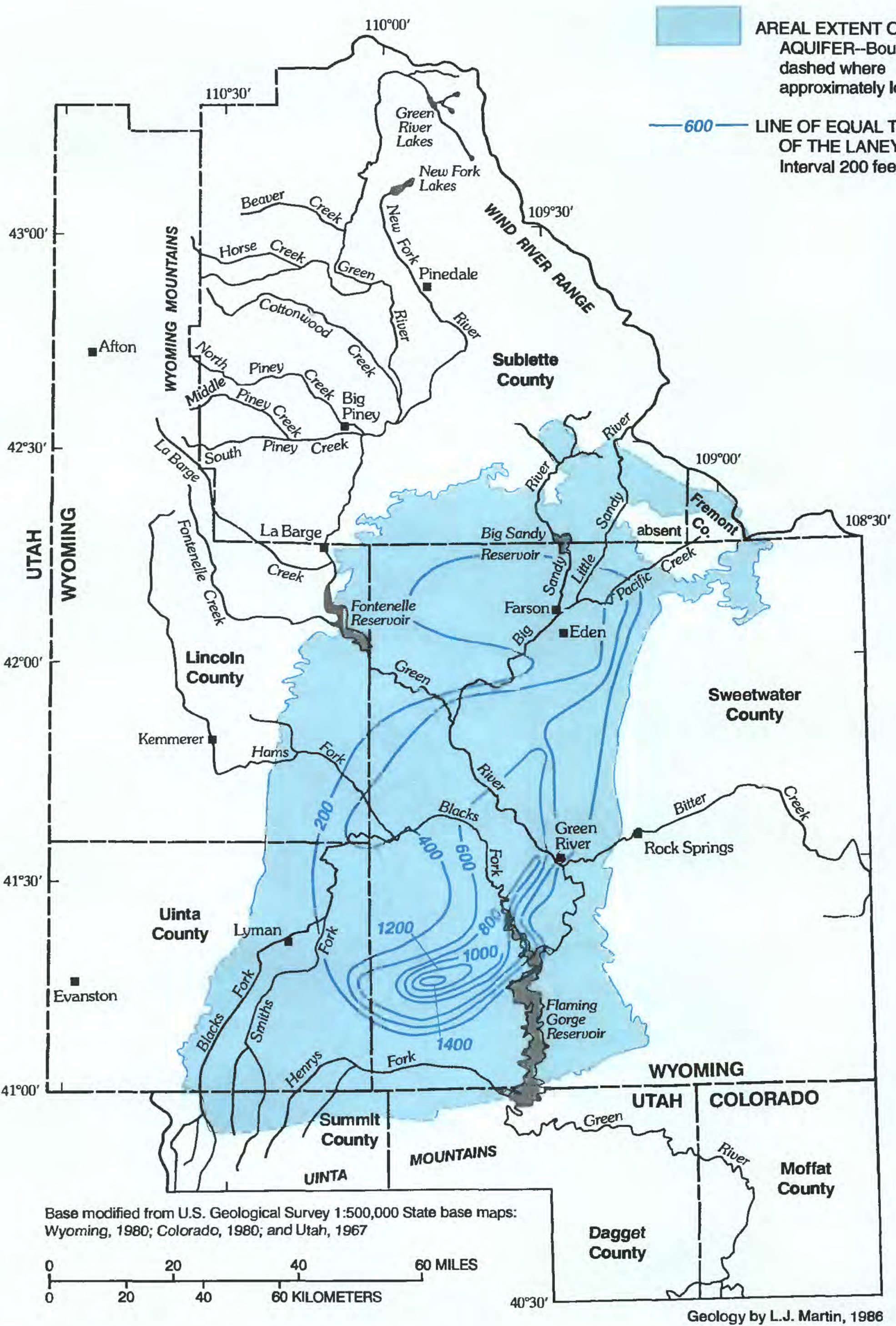

Figure 8. Thickness of the Laney aquifer in the Green River Structural Basin. 


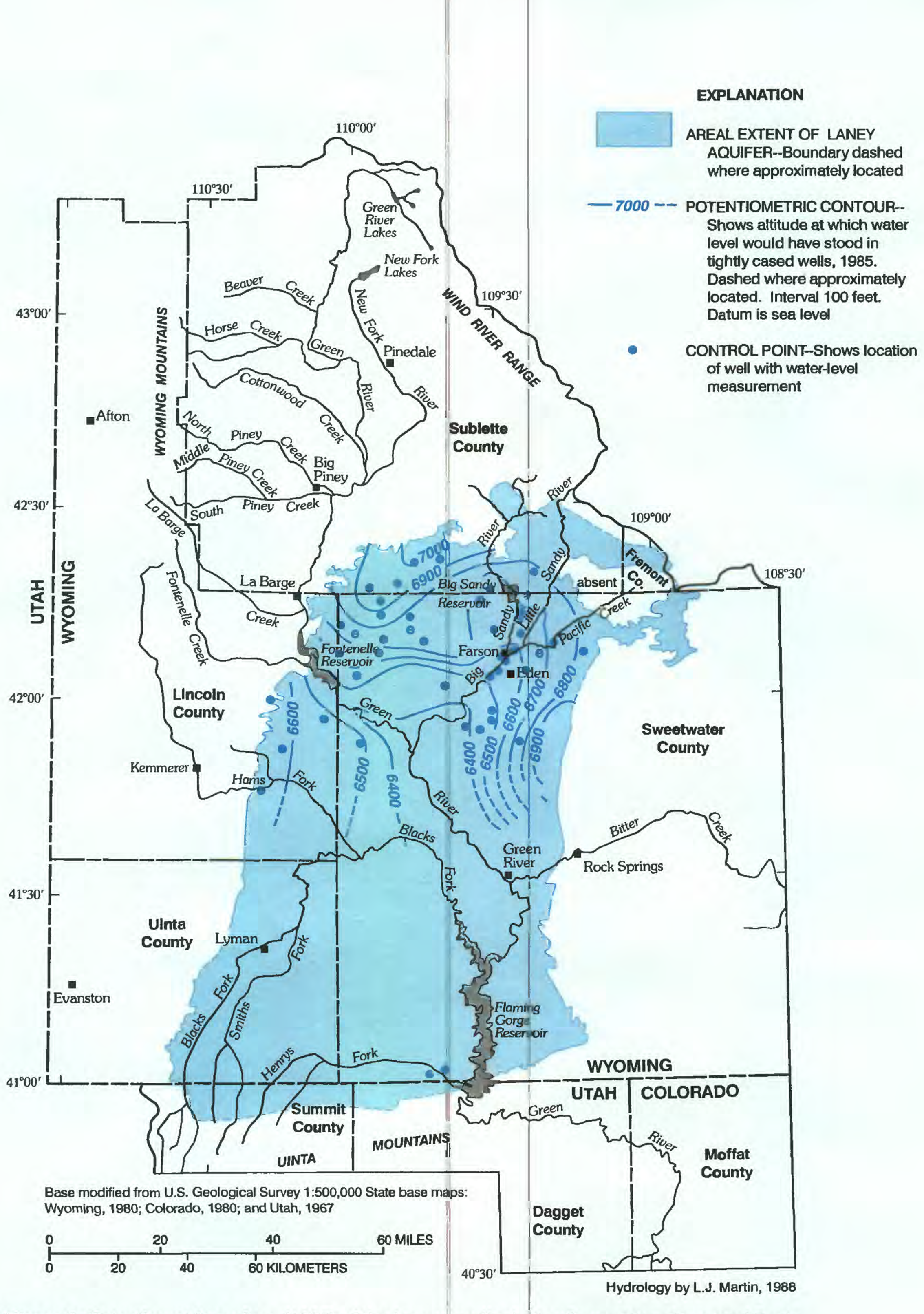

Figure 9. Potentiometric surface (1985) of the Laney aquifer in the Green River Structural Basin. 
and halite deposits (fig. 10), mapped by Bradley and Eugster (1969), effectively restrict vertical movement of water in a large area of the Wilkins Peak confining unit. Thickness of the Wilkins Peak confining unit exceeds $1,000 \mathrm{ft}$ in the southeastern part of the basin but typically is between 100 and $600 \mathrm{ft}$ (fig. 10). The Wilkins Peak confining unit has been mapped together with the Tipton confining unit near the east and southeast margins of the basin.

\section{New Fork Aquifer}

The New Fork aquifer is composed of arkosic sandstone within the New Fork Tongue of the Wasatch Formation. The aquifer is located in the central part of the Green River Basin between the overlying Wilkins Peak confining unit and the Tipton confining unit (Dana and Smith, 1973). The aquifer typically is 200 to $350 \mathrm{ft}$ thick (fig. 11). The New Fork aquifer thins to the south and is absent near the town of Green River, Wyoming. Where the Tipton confining unit is absent in the northern part of the Green River Basin, the New Fork aquifer is contiguous with and cannot be distinguished from the Wasatch zone of the Wasatch-Fort Union aquifer.

Sufficient hydraulic-head data are not available to map a potentiometric surface for the New Fork aquifer. However, flowing wells indicate that artesian conditions are common in the New Fork aquifer.

\section{Tipton Confining Unit}

The shales and marlstones of the Tipton Shale Member of the Green River Formation mainly compose the relatively thin Tipton confining unit. The Luman Tongue or Member of the Green River Formation and the Niland Tongue of the Wasatch Formation are included as part of the Tipton confining unit in the extreme southern part of the basin (fig. 3). In the central part of the Green River Basin, the Tipton confining unit separates the New Fork aquifer from the Wasatch zone of the Wasatch-Fort Union aquifer. In the southern part of the basin, where the New Fork aquifer is absent, the Tipton confining unit underlies the Wilkins Peak confining unit with which it has been mapped. Thickness of the Tipton confining unit generally ranges from 30 to $150 \mathrm{ft}$ (fig. 12).

\section{Wasatch-Fort Union Aquifer}

The Wasatch-Fort Union aquifer is composed of the Wasatch Formation and related formations and the Fort Union Formation and related formations. Together, these rocks compose the Wasatch zone and the Fort Union zone and have a total thickness of up to $11,000 \mathrm{ft}$. Both zones are hydrologically variable.

\section{Wasatch Zone}

The Wasatch zone of the Wasatch-Fort Union aquifer consists of the main body of the Wasatch Formation, the undifferentiated Green River and Wasatch Formations along the west edge of the Green River Basin, the Pass Peak Formation in the northwestern part of the basin, Oligocene and(or) Eocene and Miocene rocks in the northeastern part of the basin, and the following small tongues and members: The undifferentiated New Fork Tongue of the Wasatch Forma tion and the Fontenelle Tongue or Member of the Green River Formation, mostly between the New Fork River and the southernmost exposure of the Laney aquifer in the north and central part of the basin; the Niland Tongue of the Wasatch Formation in the southeast; the Chappo and La Barge members of the Wasatch Formation and a conglomerate member in the west; and the Luman Tongue or Member of the Green River Formation in the southeast. The main body of the Wasatch Formation is a thick sequence of fluvial sandy shale and siltstone with variable thicknesses of channel sandstone, depending on proximity to the source area of material. Thick permeable sandstones are at or near land surface in extensive areas of the northern part of the basin. In the southern part of the basin, the Wasatch zone is overlain by the Green River Formation; the number and thickness of sandstone beds in the aquifer differ areally and vertically. The amount of sandstone is sufficient for large well yields along basin margins where about $1,000 \mathrm{ft}$ of zone is penetrated. Thickness of the Wasatch zone typically ranges from about 2,000 to about $7,000 \mathrm{ft}$ (fig. 13).

The potentiometric surface of the Wasatch zone (fig. 14) was constructed primarily from water-level measurements in wells. Measurements in the northern part of the Green River Basin generally were obtained from shallow wells (less than 1,000 ft deep) and represent water-table conditions. Water-level data from shallow wells were supplemented by measurements in widely scattered wells where the aquifer is below the 
EXPLANATION

AREAL EXTENT OF WILKINS PEAK CONFINING UNIT-Boundary dashed where approximately located

- 1000 -- LINE OF EQUAL THICKNESS OF THE WILKINS PEAK CONFINING UNIT--Dashed where approximately located. Interval $\mathbf{2 0 0}$ feet

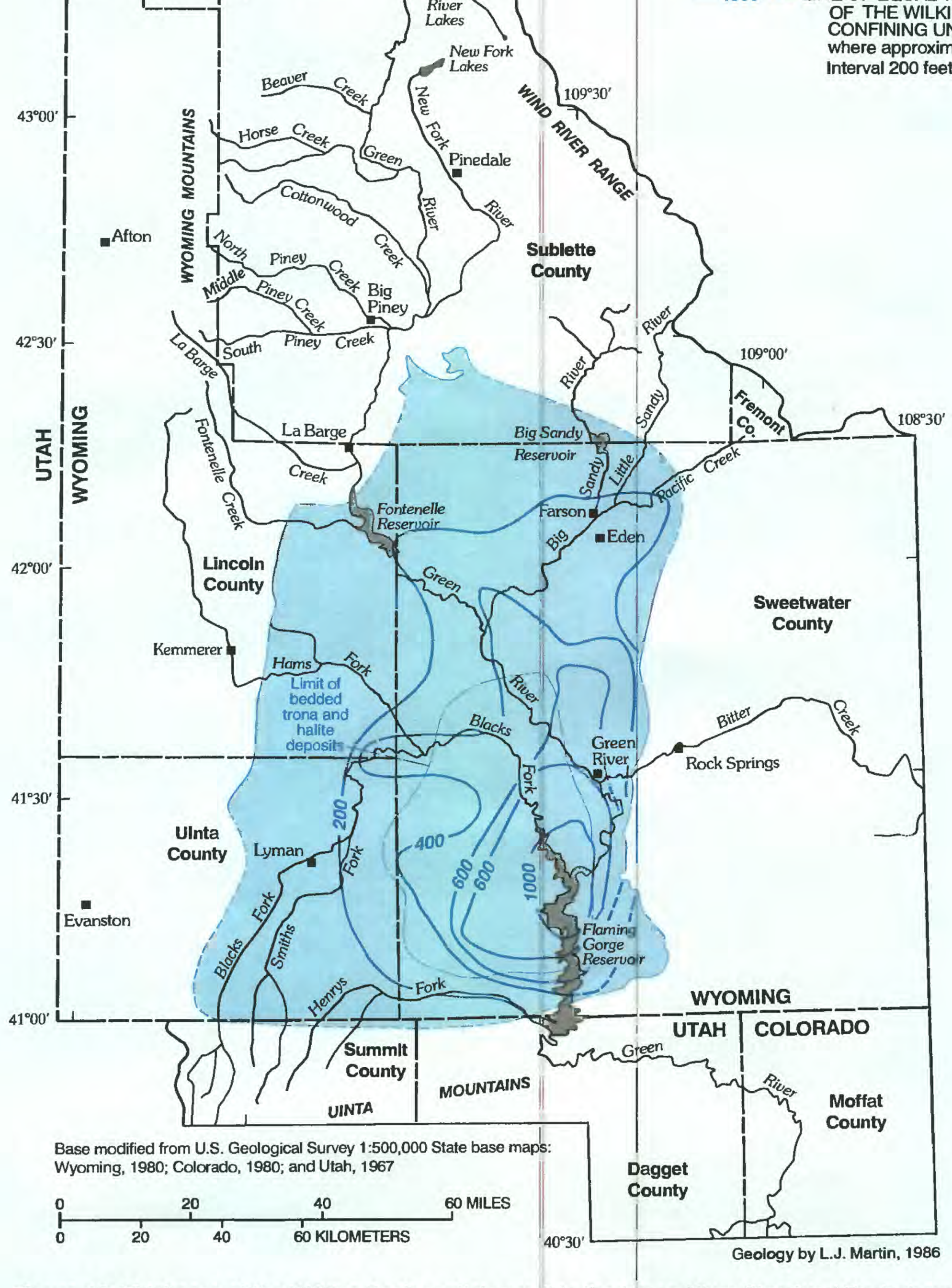

Figure 10. Thickness of the Wilkins Peak confining unit in the Green River Structural Basin (area of bedded trona and halite from Bradley and Eugster, 1969). 


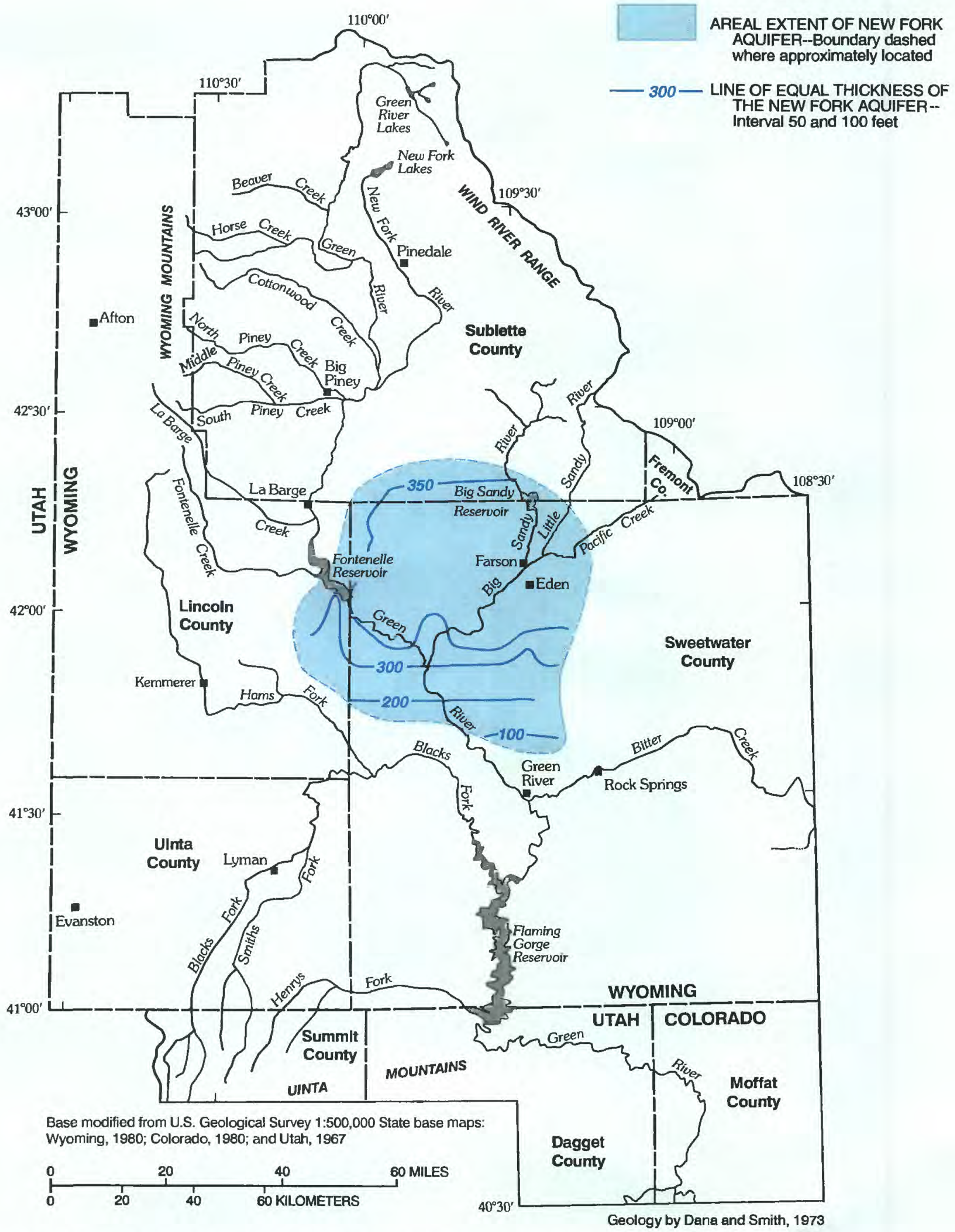

Figure 11. Thickness of the New Fork aquifer in the Green River Structural Basin. 
EXPLANATION

AREAL EXTENT OF TIPTON CONFINING UNIT--Boundary dashed where approximately located

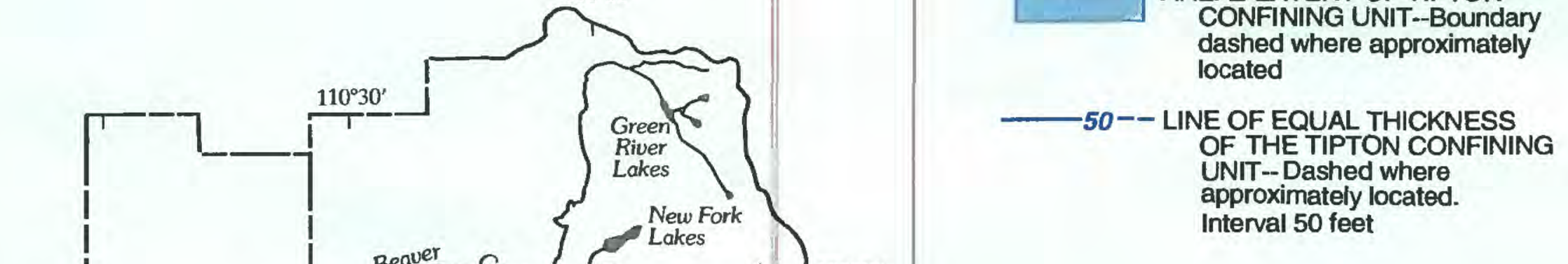




\section{EXPLANATION}

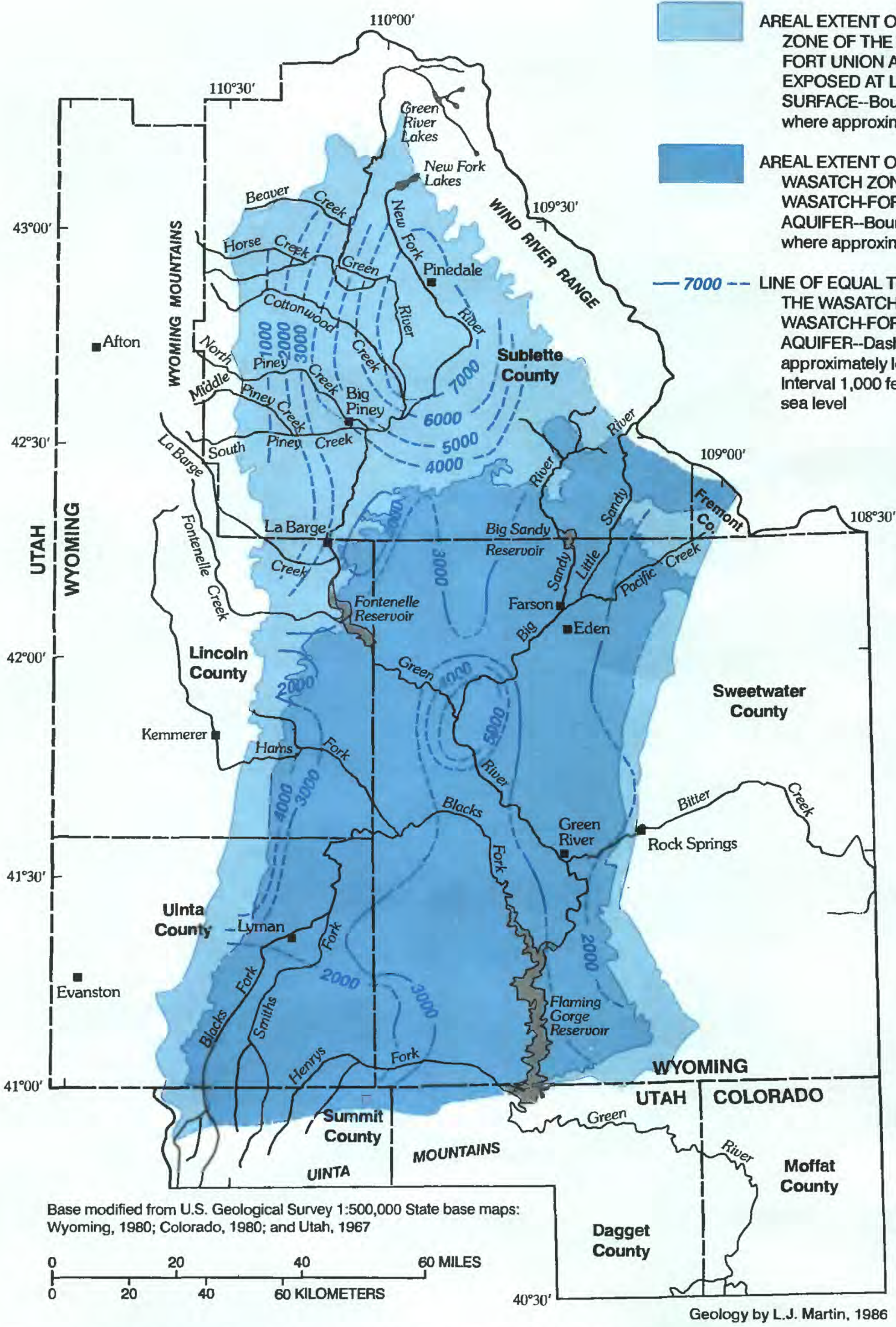

Figure 13. Thickness of the Wasatch zone of the Wasatch-Fort Union aquifer in the Green River Structural Basin. 


\section{EXPLANATION}

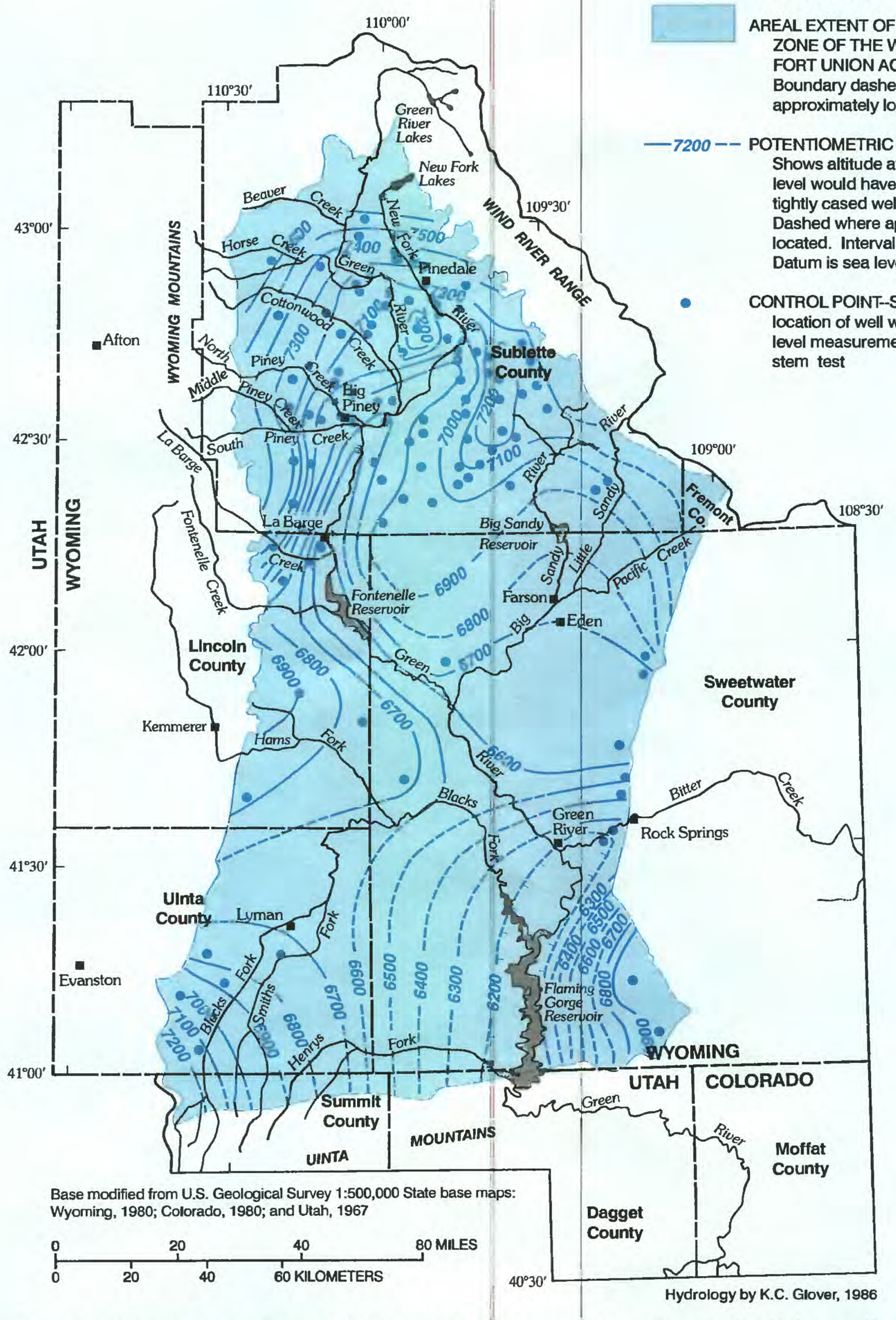

Figure 14. Potentiometric surface (1985) of the Wasatch zone of the Wasatch-Fort Union aquifer in the Green River Structural Basin. 
Tipton confining unit and the Wasatch zone is under artesian conditions. In areas where the Wasatch zone is thick, there can be substantial differences between the average hydraulic head in the deep Wasatch and the hydraulic head in the upper $1,000 \mathrm{ft}$ of the Wasatch. Shorter flow paths are predominant in the northern part of the Green River Basin where the Wasatch zone is exposed at land surface. Basin flow systems predominate where the Wasatch zone is overlain by confining units of the Green River Formation in the southern part of the basin. Ground-water flow generally is from recharge areas near the basin margins toward the center of the basin and southward. Discharge occurs as upward leakage into overlying formations, into the Green River and its tributaries, and into Flaming Gorge Reservoir. Flaming Gorge Reservoir is the principal discharge area for water following basin flow paths.

\section{Fort Union Zone}

The Fort Union zone of the Wasatch-Fort Union aquifer includes the Fort Union Formation and the Hoback Formation that mainly consist of fluvial sandstones and siltstones. The Hoback Formation is equivalent to the Fort Union Formation in the northwestern part of the Green River Basin (Love, Christiansen, and Ver Ploeg, 1992). The Fort Union zone is present throughout the Green River Basin. However, in the extreme northwestern part of the structural basin where the Hoback Formation is exposed at the surface, the Fort Union zone is not included as part of the aquifer system because it is north of a ground-water divide and outside of the hydrologic basin. Thickness of the Fort Union zone typically ranges from $2,000 \mathrm{ft}$ near the basin margins to $4,000 \mathrm{ft}$ in the central part of the basin (fig. 15).

The potentiometric surface of the Fort Union zone (fig. 16) was constructed primarily using hydraulic heads from drill-stem tests in deeply buried parts of the aquifer. Because of the use of drill-stem test results, the accuracy of the potentiometric surface for the Fort Union zone is considered to be poor. Drill-stem tests generally are conducted in Tertiary-age sediments of the Green River Basin at depths greater than $2,500 \mathrm{ft}$ and usually are recorded as occurring in the Fort Union Formation. However, such a designation is unreliable because geologists have not consistently identified the contact between the Wasatch and the Fort Union Formations.
The potentiometric surface of the Fort Union zone (fig. 16) indicates movement of ground water primarily along basin flow paths. Recharge occurs on outcrop areas and as downward leakage from overlying units near the basin margins. Discharge probably takes place as upward leakage to overlying formations in the southern part of the basin.

\section{Base of the Aquifer System}

The base of the aquifer system in Tertiary rocks in the Green River Basin is defined as the contact with Upper Cretaceous rocks (K.C. Glover, U.S. Geological Survey, written commun., 1986). This contact generally coincides with a change in lithology from fluvial sediments in Tertiary rocks to shallow marine sandstones and shales in Upper Cretaceous rocks. The altitude and configuration of the base of the aquifer system in the Tertiary rocks are shown in figure 17.

\section{GROUND-WATER FLOW}

The preceding section of the report described the geohydrologic framework or matrix within which ground water of the Green River Basin exists. The framework descriptions are here supplemented by a conceptualizaiton of the ground-water flow system existing within that framework. A five-layer computer-based groundwater flow model of the aquifer system in Tertiary rocks in the Green River Basin was developed from the conceptual flow model.

\section{Conceptual Flow Model}

The boundaries or geometry of the aquifer system, the recharge to the aquifer system, and the discharge from the aquifer system are described. In addition, a ground-water budget is estimated for the system and the direction and pattern of ground-water flow are described. Together these descriptions make up the conceptual flow model.

\section{Boundaries}

The aquifer system in Tertiary rocks in the Green River Basin is bounded on the west by the Overthrust Belt, on the south by the Uinta Mountains, on the east 
EXPLANATION

AREAL EXTENT OF FORT UNION ZONE OF THE WASATCH-FORT UNION AQUIFER

- 4000 - - LINE OF EQUAL THICKNESS OF THE FORT UNION ZONE OF THE WASATCH-FORT UNION AQUIFER--Dashed where approximately located. Interval 1,000 feet

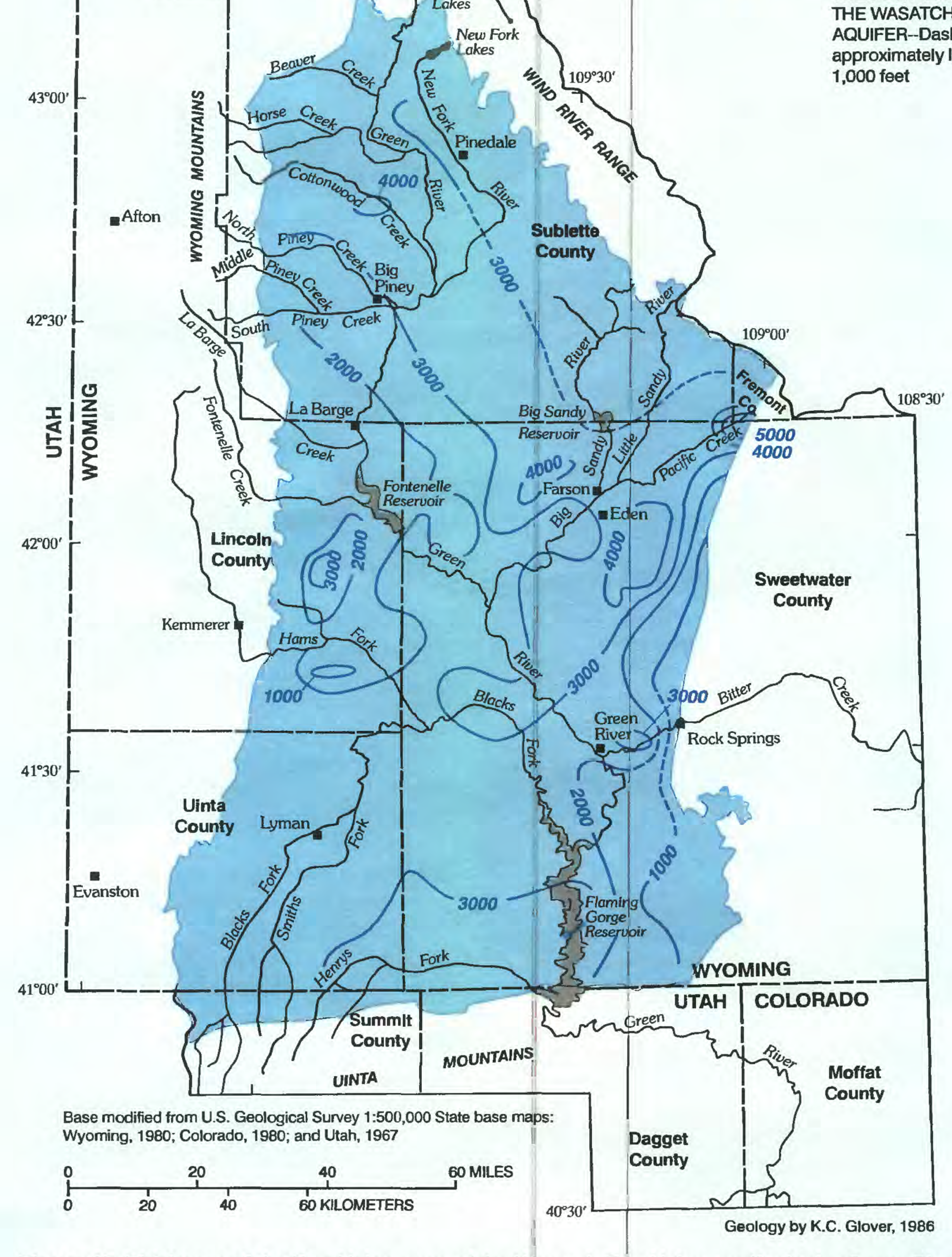

Figure 15. Thickness of the Fort Union zone of the Wasatch-Fort Union aquifer in the Green River Structural Basin. 


\section{EXPLANATION}

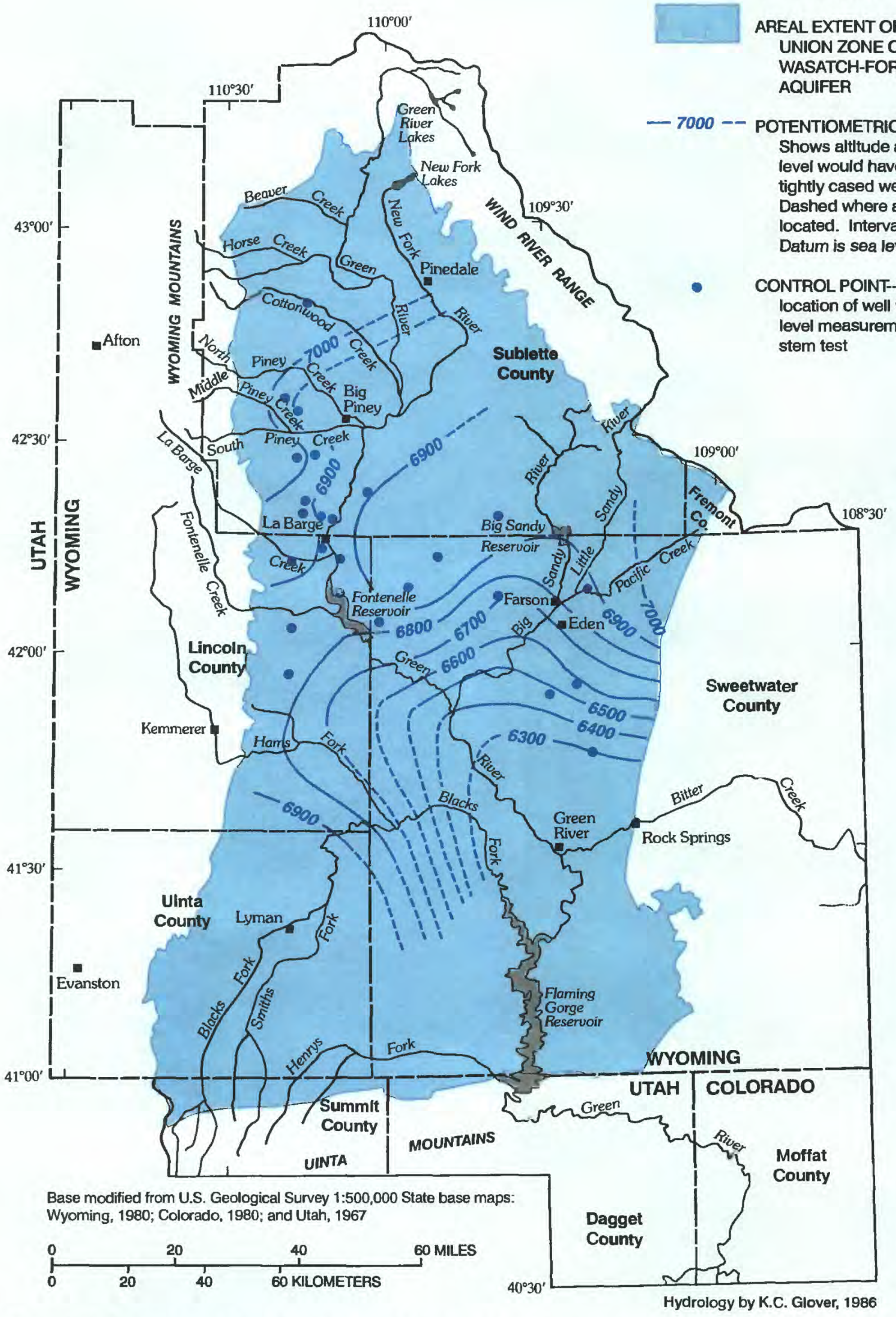

Figure 16. Potentiometric surface (1985) of the Fort Union zone of the Wasatch-Fort Union aquifer in the Green River Structural Basin. 


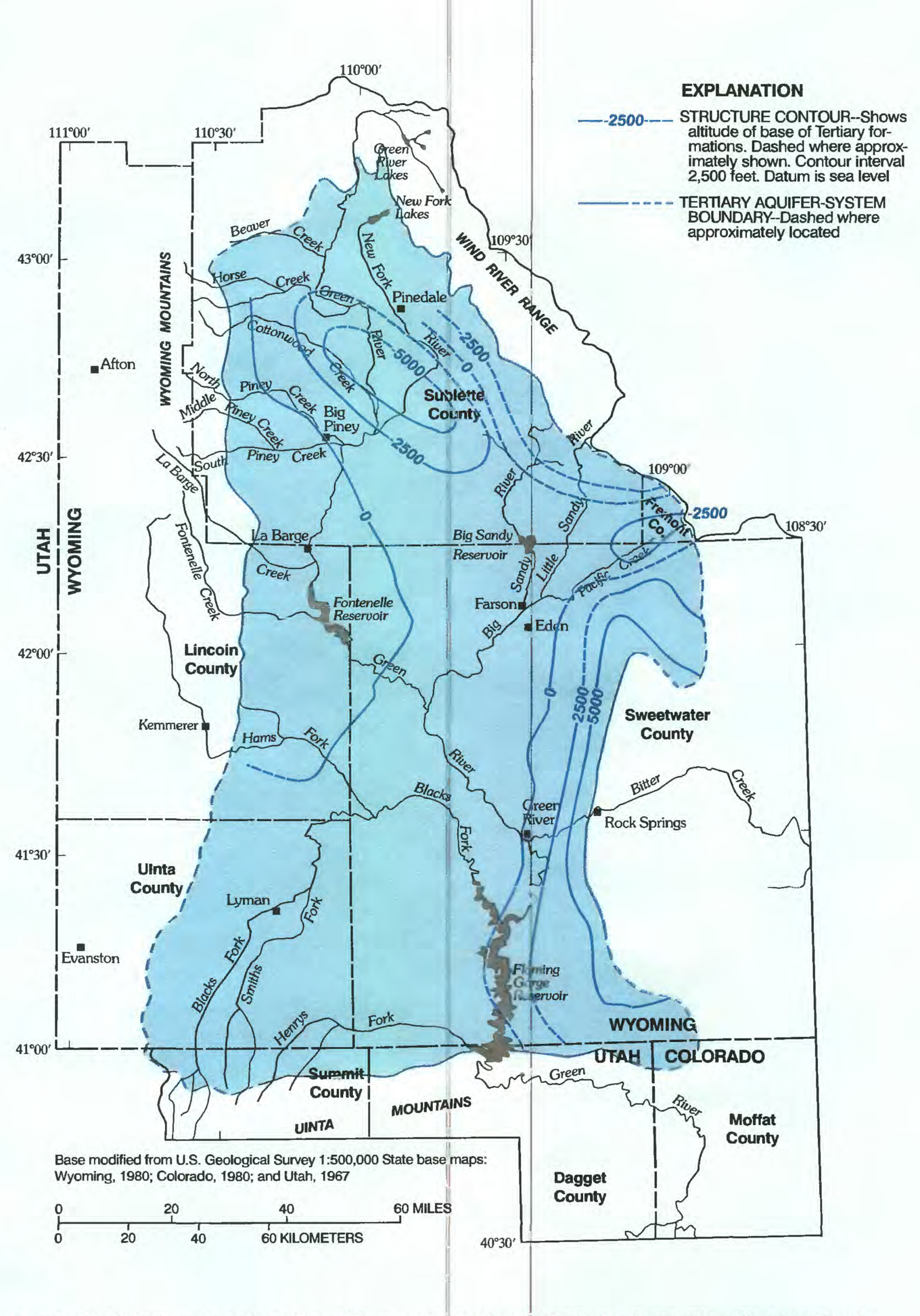

Figure 17. Altitude and configuration of the base of Tertiary rocks in the Green River Structural Basin (from Freethey and others, 1988). 
mostly by the Rock Springs Uplift, and on the northeast by the Wind River Range (fig. 2). The geologic formations along these boundaries are relatively impermeable compared to Tertiary rocks within the basin and consequently are assumed to restrict ground-water flow into and out of the basin. In the extreme northwestern part of the basin, where no ground-water data are available, the northern boundary of the aquifer system is a no-flow boundary along a ground-water divide assumed to be near the surface drainage boundary. Tertiary rocks extend into the Great Divide Basin north of the Rock Springs Uplift and into the Washakie Basin south of the uplift along the eastern boundary of the aquifer system (fig. 2). This eastern boundary of the aquifer system is a no-flow boundary along a groundwater divide in the slightly upwarped Tertiary beds between the structural basins. Potentiometric surfaces of the Wasatch and Fort Union zones of the WasatchFort Union aquifer in the Great Divide and Washakie Basins indicate that the ground-water divide north and south of the uplift is in the vicinity of the surface-water divide. In the southeastern part of the Green River Basin, the aquifer system in the Tertiary rocks is underlain by a confining unit composed of rocks of the Upper Cretaceous Lewis Shale. Elsewhere in the basin, the base of the aquifer system in the Tertiary rocks is marked by an erosional unconformity, and the Lewis Shale is absent (Ahern and others, 1981). In these areas, there may be some hydraulic connection between the Fort Union zone of the Wasatch-Fort Union aquifer and an aquifer composed of the Mesaverde Formation. However, the rate of upward leakage from the Mesaverde aquifer to the Fort Union zone is generally negligible compared to the rate of movement within the aquifer system in Tertiary rocks (Freethey and Cordy, 1991). On a basin scale, the base of the aquifer system in the Tertiary rocks is considered a noflow boundary.

\section{Recharge}

Recharge to aquifers in the Green River Basin occurs by infiltration of precipitation on outcrop areas, infiltration of snowmelt runoff from the mountains, and leakage of streamflow from tributaries of the Green River. Measurable recharge probably does not occur in the central part of the basin because of the small average annual precipitation and large evapotranspiration rates.
In areas of extensive irrigation, particularly the Farson-Eden, Wyoming area, water may percolate downward through alluvial deposits and recharge the underlying Laney aquifer (Ahern and others, 1981). Recharge in this area was estimated as $18 \mathrm{ft}^{3} / \mathrm{s}$ (cubic foot per second) during calibration of the numerical flow model.

Analysis of streamflow-gaging records of the major streams in the Green River Basin indicates that all are gaining streams, except for the Blacks Fork, Smiths Fork, and Hams Fork. The Blacks Fork, Smiths Fork, and Hams Fork are losing streams and presumably recharge the underlying aquifers or are losing because of evapotranspiration from vegetation along the stream courses. Cumulative loss from these three streams is estimated to be $9 \mathrm{ft}^{3} / \mathrm{s}$.

Estimates of ground-water recharge were made by using a method developed by Eakin and others (1951) and modified by Hood and Waddell (1968). The method is based on an empirically derived assumption that recharge can be estimated as a percentage of average annual precipitation. The percentage of precipitation effective as recharge is assumed to increase as precipitation increases. The actual percentage used to estimate recharge is obtained in a subjective manner that accounts for differences in surficial geology, physiography, and seasonal precipitation patterns.

Recharge in areas receiving less than $10 \mathrm{in.} \mathrm{of} \mathrm{precipi-}$ tation annually is assumed to be negligible. When using the method of Hood and Waddell (1968), recharge from precipitation, snowmelt, streams, and canals, is not estimated separately. The percentage values used in estimating recharge from precipitation are adjusted to account for these sources of water. Areal distribution of ground-water recharge for the Green River Basin is shown in figure 18. Recharge estimates range from 0 to $2.6 \mathrm{in} / \mathrm{yr}$ and were extended to the model boundary in areas where the estimate did not extend that far.

Total recharge to the ground-water system is estimated to be about $165 \mathrm{ft}^{3} / \mathrm{s}$ : $138 \mathrm{ft}^{3} / \mathrm{s}$ from infiltration of precipitation, snowmelt runoff, and streamflow $\left(117 \mathrm{ft}^{3} / \mathrm{s}\right.$, northern Green River Basin; $21 \mathrm{ft}^{3} / \mathrm{s}$, southern Green River Basin); $18 \mathrm{ft}^{3} / \mathrm{s}$ from excess applied irrigation water in the Farson-Eden, Wyoming area (east-central part of the basin); and the previously mentioned questionable streamflow leakage of $9 \mathrm{ft}^{3} / \mathrm{s}$ from the Blacks Fork, Smiths Fork, and Hams Fork. 


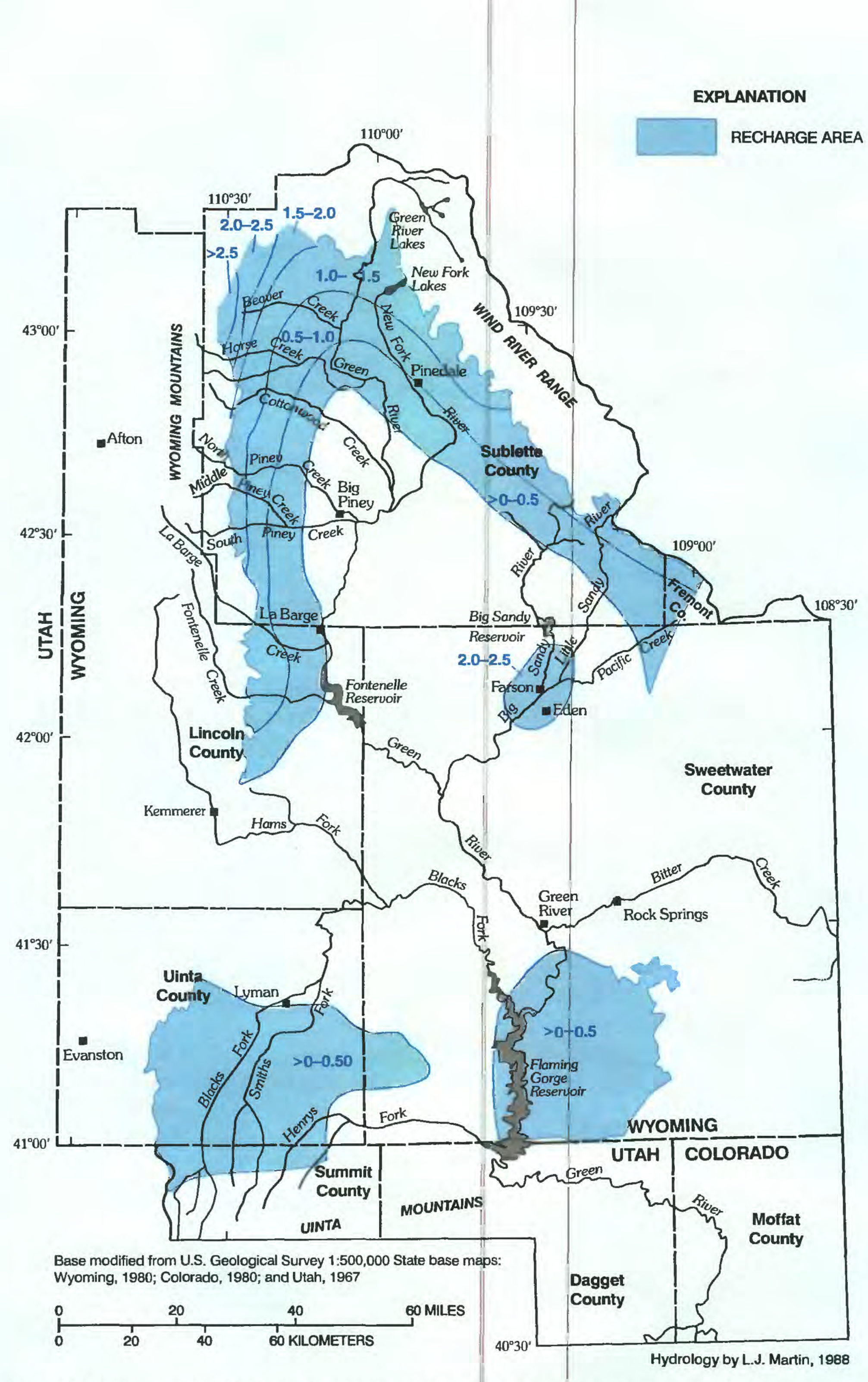

Figure 18. Estimated distribution of ground-water recharge, in inches per year, in the Green River Structural Basin. 


\section{Discharge}

Ground-water discharge occurs principally as seepage to the Green River, to major tributaries of the Green River, and to Flaming Gorge Reservoir. Smaller streams, particularly in the northern part of the Green River Basin, probably receive discharge from local flow systems. Minor discharge from the aquifer system is through small springs issuing from the Bridger aquifer in the southern part of the basin and the Laney aquifer in the Farson-Eden, Wyoming area (Ahern and others, 1981). Discharge from the basin ground-water flow system by pumping from wells and by evapotranspiration is negligible. Ground-water discharge from the basin ground-water flow system is assumed to be fairly constant and can be reasonably estimated using January streamflow records.

January streamflow data from gaging stations on the Green River and its major tributaries were used to estimate the distribution of ground-water discharge to streams in the Green River Basin. January streamflow was used because the effects of diversions, evapotranspiration, and precipitation runoff are negligible during this month. The quantity of ground-water discharge to stream reaches was estimated by calculating the difference between average streamflow at upstream and downstream stations and subtracting the estimated average inflow from tributaries between the gaging stations. The accuracy of the streamflow data for January can be affected at some stations. Ice-affected streamstage records result in less accurate measurement of streamflow; in some cases streamflow must be estimated rather than measured. However, the accuracy of the average January streamflow for the period of record of this study is not significantly affected. Groundwater discharge to streams could not be estimated on reaches for which the period of record at upstream and downstream gaging stations does not overlap, reaches where streamflow from major tributaries was not measured, and reaches having reservoirs. Ground-water discharge to Flaming Gorge Reservoir was estimated from streamflow-gaging records prior to construction of the reservoir.

Total ground-water discharge to the major streams was estimated to be $163 \mathrm{ft}^{3} / \mathrm{s}$ : $94 \mathrm{ft}^{3} / \mathrm{s}$ to the Green and New Fork Rivers upstream from Fontenelle Reservoir, $23 \mathrm{ft}^{3} / \mathrm{s}$ to the Green River between Fontenelle and the town of Green River, Wyoming, $13 \mathrm{ft}^{3} / \mathrm{s}$ to the Green River downstream from the town of Green River, including Flaming Gorge Reservoir, $17 \mathrm{ft}^{3} / \mathrm{s}$ to the Big Sandy River, and $16 \mathrm{ft}^{3} / \mathrm{s}$ to Henrys Fork.

\section{Estimated Steady-State Ground-Water Budget}

The ground-water system in Tertiary rocks in the Green River Basin is in a state of dynamic equilibrium. The volume of water recharging the basin groundwater system is balanced by an equal volume of discharge. Potentiometric surfaces of the aquifers are stable, and the quantity of water in storage is constant. Water is transmitted from recharge areas to discharge areas at a rate determined by the transmissivity of the aquifer and the gradient of the potentiometric surface.

A budget for the ground-water system was prepared by summing inflow to and outflow from the system (table 2). Inflow of water to the ground-water system is derived from infiltration of precipitation, snowmelt runoff, streamflow, and excess irrigation water. Outflow occurs as ground-water discharge to streams and to Flaming Gorge Reservoir. Discharge from the basin ground-water flow system through wells and by evapotranspiration is negligible. The groundwater budget does not balance precisely because the values are estimated and rounded.

Table 2. Estimated steady-state ground-water budget for Tertiary rocks in the Green River Basin

\begin{tabular}{|c|c|}
\hline Recharge components & $\begin{array}{l}\text { Inflow to the ground- } \\
\text { water system } \\
\text { (cubic feet per second) }\end{array}$ \\
\hline $\begin{array}{l}\text { Infiltration of precipitation, } \\
\text { snowmelt runoff, and streamflow }\end{array}$ & 138 \\
\hline $\begin{array}{l}\text { Excess irrigation water in the } \\
\text { Farson-Eden, Wyoming area }\end{array}$ & 18 \\
\hline $\begin{array}{l}\text { Streamflow leakage along the } \\
\text { Blacks Fork, Smiths Fork, and } \\
\text { Hams Fork }\end{array}$ & 9 \\
\hline Total & 165 \\
\hline Discharge components & $\begin{array}{l}\text { Outflow from the } \\
\text { ground-water system } \\
\text { (cubic feet per second) }\end{array}$ \\
\hline $\begin{array}{l}\text { Green and New Fork Rivers } \\
\text { upstream from Fontenelle } \\
\text { Reservoir }\end{array}$ & 94 \\
\hline $\begin{array}{l}\text { Green River between Fontenelle } \\
\text { Reservoir and the town of Green } \\
\text { River, Wyoming }\end{array}$ & 23 \\
\hline $\begin{array}{l}\text { Green River downstream from the } \\
\text { town of Green River, Wyoming, } \\
\text { including Flaming Gorge } \\
\text { Reservoir }\end{array}$ & 13 \\
\hline Big Sandy River & 17 \\
\hline Henrys Fork & 16 \\
\hline Total & 163 \\
\hline
\end{tabular}




\section{Flow Direction and Pattern}

Ground-water flow in the aquifer system in Tertiary rocks in the Green River Basin generally is from recharge areas along most of the periphery of the basin toward the center of the basin and southward. Groundwater flow is shown schematically in figure 19.

Ground-water flow in the Bridger aquifer is primarily horizontal along short and long flow paths. Substantial vertical leakage into deeper aquifers occurs only along the Uinta Mountains where the underlying aquifer in the Green River Formation is conglomeratic (Bradley, 1964). Ground water in the Bridger aquifer flows from recharge areas along the Uinta Mountains toward the north and northeast, and discharges along streams.

Rates of ground-water flow in the Laney aquifer are greatest where the Laney is at land surface and hydraulic conductivity is enhanced by fracturing. Flow in the Laney aquifer, where buried by the Bridger aquifer, is much less. Water enters the Laney aquifer by recharge from irrigation in the Farson-Eden, Wyoming area and by upward leakage from the New Fork aquifer through the Wilkins Peak confining unit. In addition, water enters the Laney aquifer along long flow paths by lateral flow from the Wasatch zone of the Wasatch-Fort Union aquifer in the north, and from the Bridger aquifer. Virtually no water leaks upward into the Laney aquifer in areas underlain by bedded trona deposits of the Wilkins Peak confining unit in the central part of the basin. Most water discharged from the Laney aquifer flows into the Big Sandy River and the Green River between Fontenelle Reservoir and the town of Green River, Wyoming

Water enters the New Fork aquifer laterally from the Wasatch zone of the Wasatch-Fort Union aquifer to the north, and by upward leakage from the underlying Wasatch zone through the Tipton confining unit. Hydraulic heads in wells completed in the New Fork aquifer indicate that ground water in the New Fork aquifer flows in a southerly direction and discharges by upward leakage into the Laney aquifer through the Wilkins Peak confining unit. Most of the discharge to the Laney aquifer occurs along the Green River between Fontenelle Reservoir and the mouth of the Big Sandy River.
Ground-water flow in the Wasatch and Fort Union zones of the Wasatch-Fort Union aquifer occurs along short, long, and basin flow paths. Flow along short flow paths is most common where the Wasatch and Fort Union zones are at land surface near basin margins. Recharge to these local flow systems is from infiltration of precipitation and snowmelt on outcrop areas; discharge is to tributaries of the Green River adjacent to and a short distance from the recharge areas.

Most water in the Wasatch and Fort Union zones flows along long flow paths. Flow in the Wasatch and Fort Union zones occurs from recharge areas adjacent to the Wind River Range on the north and Overthrust Belt on the west to discharge areas along the upper reaches of the Green and New Fork Rivers; flow along long flow paths also occurs from recharge areas south of the Rock Springs Uplift to discharge at Flaming Gorge Reservoir.

Basin flow occurs in deep parts of the Wasatch and Fort Union zones and where the Wasatch zone is overlain by the Tipton confining unit. In the northern part of the Green River Basin, substantial volumes of water leak downward from shallow parts of the Wasatch and Fort Union zones, then flow horizontally to the south. In the southern part of the basin, water enters the Wasatch and Fort Union zones by recharge and downward leakage along the Uinta Mountains to the south and flows horizontally north to Flaming Gorge Reservoir. The area of the Flaming Gorge Reservoir is the principal locus of discharge for the basin flow system. Discharge in the area of the reservoir occurs by upward leakage to overlying aquifers in the Green River Formation.

\section{Numerical Flow Model}

A five-layer computer-based ground-water flow model of the aquifer system in Tertiary rocks in the Green River Basin was developed. The simulation program used was the U.S. Geological Survey modular three-dimensional finite-difference ground-water flow model (McDonald and Harbaugh, 1988), a program evolved from the two- and three- dimensional finitedifference models of Trescott (1975) and Trescott, Pinder, and Larson (1976). 


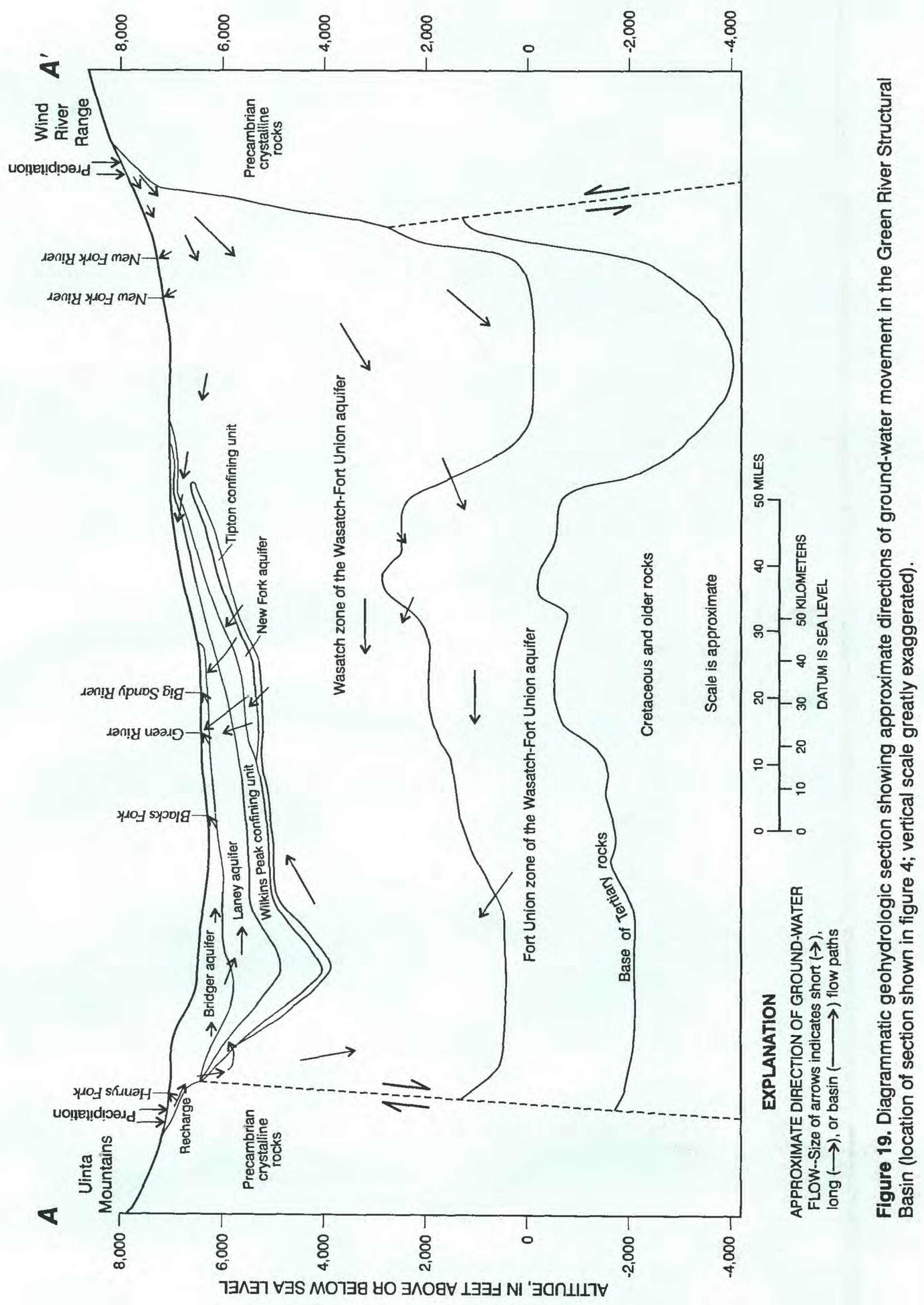

GROUND-WATER FLOW 29 


\section{Model Design}

\section{Finite-Difference Grid}

The study area was divided into a grid of variably sized, rectangular cells in a north-south and east-west orientation (fig. 20); the border of the grid approximates the aquifer-system boundary. In each cell, the aquifer properties are assumed to be uniform. Cell dimensions range from 15,000 to $20,000 \mathrm{ft}$ in the eastwest direction and from 15,000 to $25,000 \mathrm{ft}$ in the north-south direction. The grid size selected was the result of a compromise to limit the quantity of cells to a manageable number while maintaining a sufficient number of cells to give a reasonable depiction of the available data. The vertical dimension of the cells in each layer represents the average thickness of the model layer. The thickness of each model layer varies to simulate the varying thickness of the geohydrologic unit. Vertical thicknesses were determined by digitizing information from thickness maps onto a grid overlay.

Ground-water flow across the boundaries of the aquifer system was assumed to be negligible. Therefore, a no-flow boundary (cells with transmissivity equal to zero) was inserted around the border of each layer of the grid. Stream-aquifer leakage was simulated at river cells where variable flow into or out of the aquifer was simulated. Fixed, specified recharge was simulated at the recharge cells shown on the finite-difference grid (fig. 20).

\section{Model Layers}

The five layers of the model correspond to geohydrologic units in the basin as shown in table 3 and figure 21. Confining units generally are not treated as active separate layers in this study but are represented by vertical conductance terms between the nodes of active model layers. One exception is the southern part of layer 3 that represents the area where the Wilkins Peak and Tipton confining units are vertically contiguous.

The Wasatch zone of the Wasatch-Fort Union aquifer in the northern part of the basin was subdivided into three layers $(2,3$, and 4$)$ for the flow-model simulation. Use of three Wasatch layers aids in simulating short flow paths within the model; in facilitating changes in hydraulic conductivity with depth of burial; and in avoiding potential problems in the equationsolving algorithm. The Wasatch zone in layer 2 of the model was assigned a thickness of $300 \mathrm{ft}$. The Wasatch zone in layer 3 of the model was assigned a thickness of $500 \mathrm{ft}$.l The Wasatch zone in layer 4 was set equal to the remaining Wasatch thickness.

\section{Required Data}

Ground-water recharge from infiltration of precipitation, snowmelt runoff, and streamflow was calculated as described in a preceding section and generally distributed as indicated by the recharge cells in the finite-difference grid (fig. 20). Minor adjustments of the recharge due to infiltration of precipitation were made during calibration of the flow model.

Data for simulating stream-aquifer leakage were estimated using 7.5-minute topographic quadrangle maps and water-resources data reports. Data included the location of each river cell, altitude of the river stage, altitude of the riverbed, and riverbed hydraulic conductance. Blacks Fork and Smiths Fork were combined and simulated by one set of river cells because of the large cells and the proximity of the two streams. The riverbed hydraulic conductance was calculated from average or estimated values for length and width of the riyer in each cell, thickness of the riverbed, and hydraulic conductivity of the riverbed material. Thickness of the riverbed material was assumed to be $1 \mathrm{ft}$. Vertical hydraulic conductivity of the riverbed material was estimated to be $0.1 \mathrm{ft} / \mathrm{d}$. These estimates are in general agreement with the values used by Glover (1983) for Bates Creek in central Wyoming and for the Bear River in western Wyoming (Glover, 1990). Data for simulating stream-aquifer leakage were not adjusted during calibration and simulation.

Each layer of the model was subdivided into subareas within which only one value of horizontal and one value of vertical hydraulic conductivity were used. Division into subareas was made on the basis of variations in geology or differences in hydraulic properties inferred from changes in the gradient of potentiometric surfaces. Estimates of horizontal hydraulic conductivity (table 1) obtained from aquifer tests, drill-stem tests, and a numerical ground-water flow model initially were used in the model. Published estimates of vertical hydraulic conductivity are not available in the Green River Basin. Vertical hydraulic conductivity of aquifers initially was estimated to be equal to the horizontal hydraulic conductivity divided by 100 . Vertical hydraulic conductivity of confining layers initially was estimated at $0.00001 \mathrm{ft} / \mathrm{d}$. 


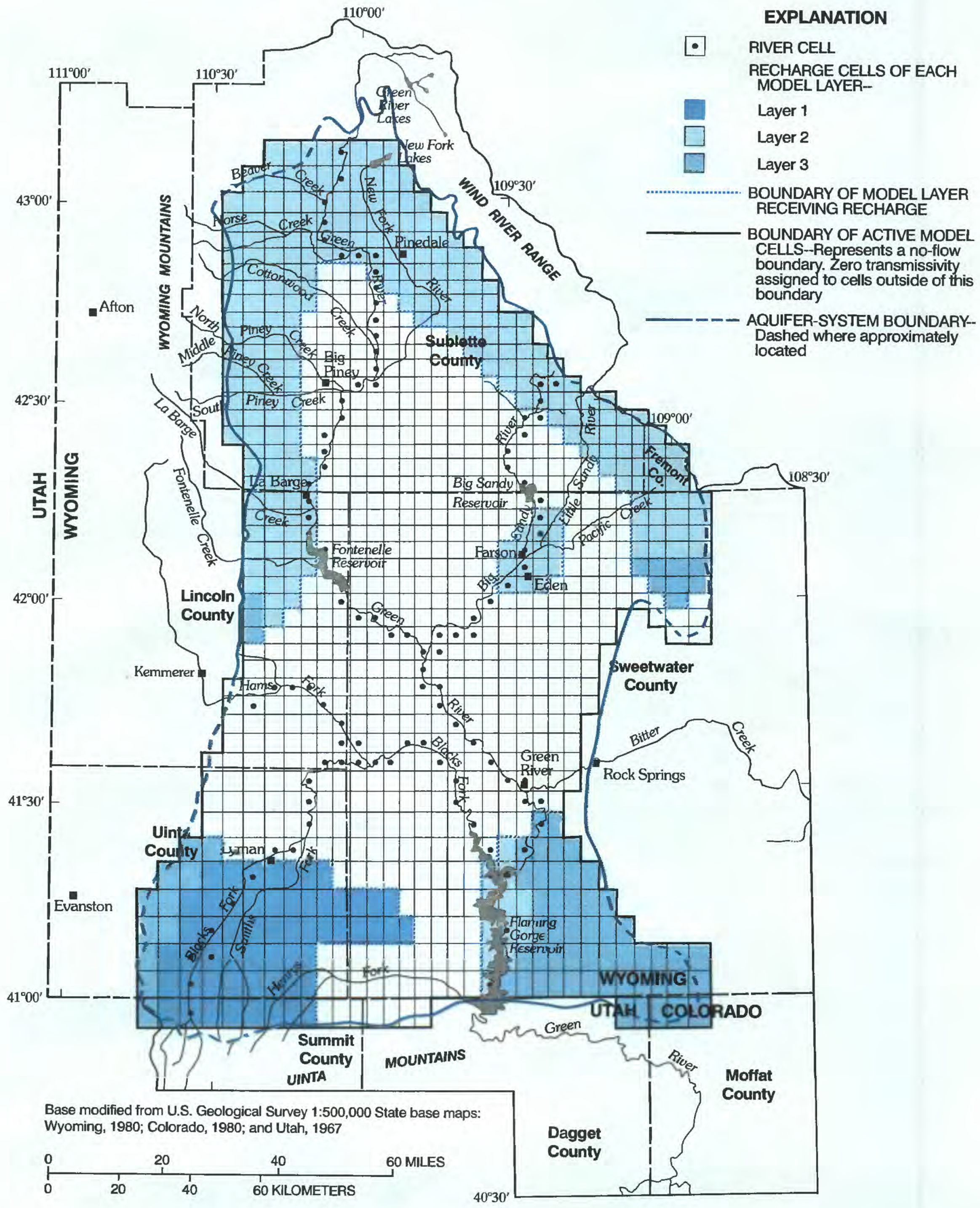

Figure 20. Finite-difference grid showing river cells and the distribution of recharge to model layers in the Green River Structural Basin. 
Table 3. Relation of model layers to geohydrologic units

\begin{tabular}{l} 
Model layer number \\
\cline { 2 - 4 } Laney aquifer
\end{tabular}

Transmissivity was calculated from values of horizontal hydraulic conductivity and layer thicknesses; vertical conductance was calculated from vertical hydraulic conductivity, layer thickness, and cell area. Hydraulic conductivities were adjusted during model calibration. Data required for the simulation included model geometry and starting heads, recharge and stream-aquifer leakage, and division of hydraulic properties into subareas within model layers. Layer thickness, grid size, and starting hydraulic heads were held constant during calibration of the model.

\section{Model Calibration}

The ground-water flow model was calibrated for steady-state conditions by a trial-and-error process. Ground-water development in the Green River Basin is too sparse to warrant development of a transient model on a basin scale. The hydraulic conductivity was adjusted until a reasonable match of stream-aquifer leakage and hydraulic-head data was achieved between the conceptual model and the simulated model. Simulation of a historical period of record showing basin water-level changes was not possible because data documenting historical ground-water levels were not available. Calibration criteria for the model were (1) to minimize the differences between the estimated and simulated stream-aquifer leakage, and (2) to minimize the differences between the measured and simulated hydraulic heads.

\section{Stream-Aquifer Leakage}

The first criterion for model calibration was to simulate stream-aquifer leakage such that it approximated the estimated stream-aquifer leakage. Most of the estimated stream-aquifer leakage consisted of ground-water leakage to streams. After each model run, the simulated ground-water leakage to streams was cornpared to the estimated leakage. Adjustments were made to the hydraulic conductivity estimates within the various subareas, and the simulation was repeated. A comparison between the estimated and the simulated stream-aquifer leakage for the calibrated flow model is listed in table 4.

With the exception of Blacks Fork, Smiths Fork, and Hams Fork, ground-water discharge to streams simulated by the basin flow model compares well with estimated streamflow gain. The potentiometric surface of the Bridger aquifer indicates that ground water probably discharges into Blacks Fork and Smiths Fork; however, streamflow-gaging data indicate that Blacks Fork and Smiths Fork are losing streams. It is possible 

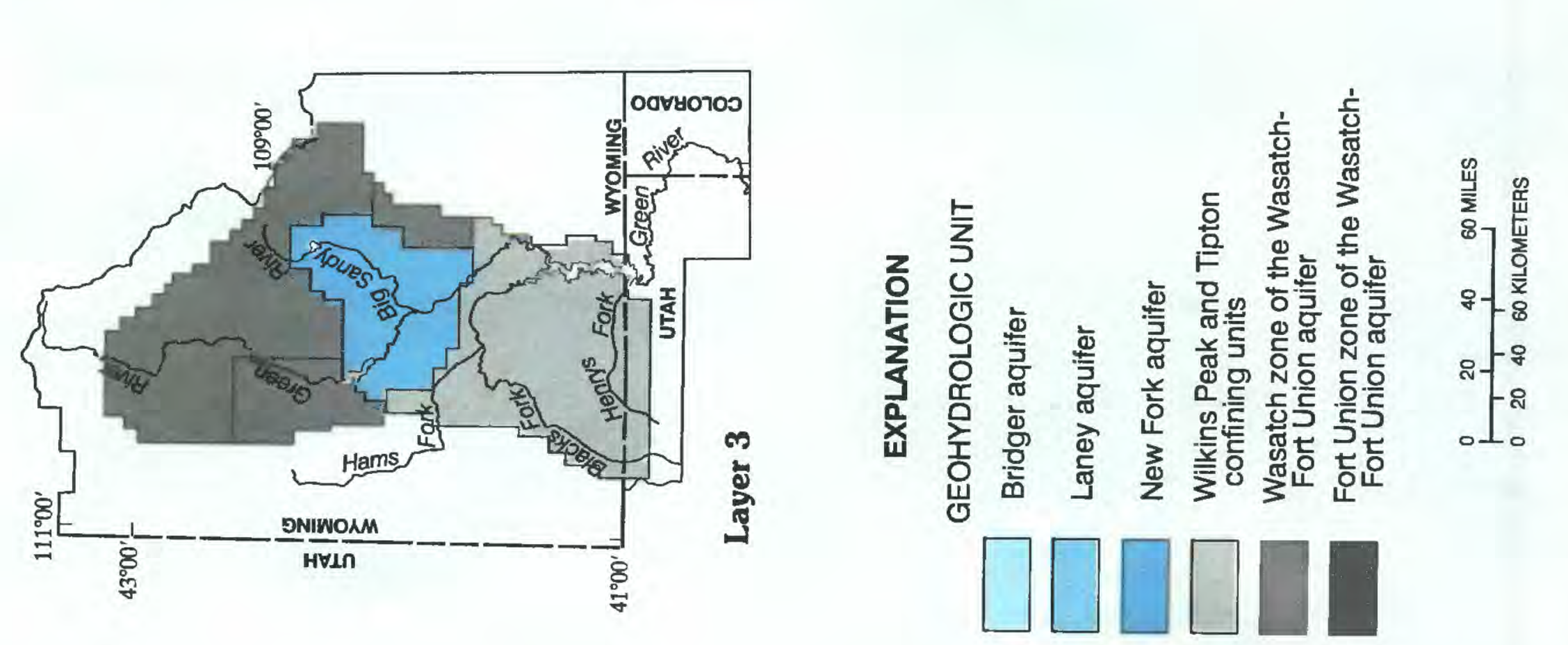


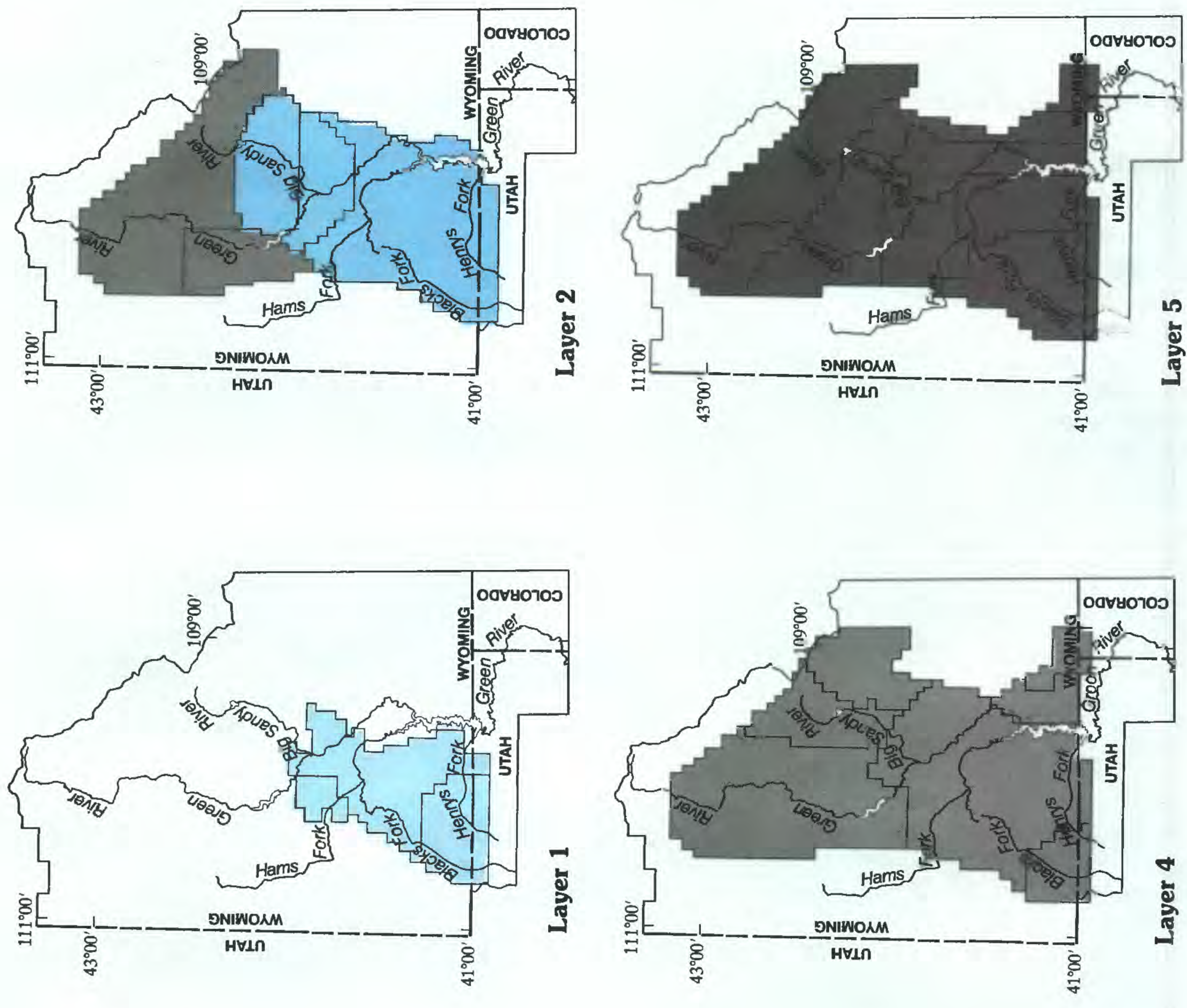

然 
Table 4. Estimated and simulated stream-aquifer leakage

[+, ground-water leakage to stream (streamflow gain); -, streamflow leakage to aquifer (strearhflow loss); --, not simulated]

\begin{tabular}{l|cc}
\hline \multicolumn{1}{c}{ Stream reach } & \multicolumn{2}{c}{$\begin{array}{c}\text { Stream-aquifer leakage, } \\
\text { in cubic feet per second }\end{array}$} \\
\cline { 2 - 3 } & $\begin{array}{c}\text { Estimated from } \\
\text { streamflow-gaging data }\end{array}$ & $\begin{array}{c}\text { Simulated by flow- } \\
\text { model analysis }\end{array}$ \\
\hline Green and New Fork Rivers upstream from Fontenelle Reservoir & +94 & +98 \\
Green River between Fontenelle Reservoir and the town of Green River, & +23 & +23 \\
$\quad$ Wyoming & +13 & +14 \\
Green River downstream from the town of Green River, Wyoming including & & +12 \\
$\quad$ Flaming Gorge Reservoir & +17 & $2+9$ \\
Big Sandy River & -9 & -- \\
Blacks Fork, Smiths Fork, and Hams Fork & +16 & +16 \\
Henrys Fork & &
\end{tabular}

${ }^{1}$ New Fork River was not simulated.

${ }^{2}$ Blacks Fork and Smiths Fork simulated as one stream (see fig. 20).

that evapotranspiration due to vegetation along the stream banks causes these streams to be losing streams, whereas ground water also is lost to evapotranspiration along the same reaches. However, additional study along these drainages would be necessary to gain understanding of the local hydrology.

Recharge from irrigation in the Farson-Eden, Wyoming area was estimated by the trial-and-error method until a satisfactory match between estimated and simulated ground-water discharge to the Big Sandy River was achieved. Flow model analysis indicated that ground-water recharge in the Farson-Eden, Wyoming area was needed to simulate streamflow gains from ground-water discharge to the Big Sandy River downstream from the irrigated area.

\section{Hydraulic Heads}

The second criterion for calibration of the ground-water flow model was evaluated by comparing the RMS (root-mean-square) deviation between simulated and measured hydraulic heads. Specifically, the RMS deviation is a measure of the mean departure of the simulated heads from the starting heads. First, only those grid cells with measured heads were used in the calculations to determine the RMS deviation. Second, all starting heads, measured and interpolated, were used in the calculations to determine the RMS deviation. Additional model runs using the trial-and-error method of adjusting parameters were made to try to produce a better agreement between simulated and measured head data. Decreases in the RMS deviation below about $250 \mathrm{ft}$ (for the Laney aquifer) adversely affected the agreement between simulated and measured stream-aquifer leakage and further adjustments were abandoned. The RMS deviation between the final simulated heads and the measured heads for the Bridger and Laney aquifers and the Wasatch and Fort Union zones of the Wasatch-Fort Union aquifer is listed in table 5. The RMS deviation between the final simulated heads and the measured plus interpolated starting heads at all grid cells is listed in table 6 . The RMS deviations on table 6 generally are smaller than those on table 5. The difference between tables 5 and 6 is an indication that the model is in general hydrologic agreement with interpolated starting heads.

One of the objectives of calibrating the flow model was to simulate the unmeasured flow patterns in the New Fork aquifer. Simulated horizontal flow enters the New Fork aquifer from the Wasatch zone of the Wasatch-Fort Union aquifer from the north. Water in the New Fork aquifer flows in a southerly direction and discharges by upward flow to the Laney aquifer (fig. 22).

Areas of substantial vertical flow (greater than $0.1 \mathrm{ft}^{3} / \mathrm{s} /$ model cell) between layers of the model are shown in figure 23. Substantial simulated upward flow from the New Fork aquifer occurred near Fontenelle Reservoir and at the northernmost extent of the New Fork aquifer (fig. 23). In addition, substantial upward flow to the New Fork aquifer was simulated from the underlying Wasatch zone of the Wasatch-Fort Union aquifer near Fontenelle Reservoir. 
Table 5. Root-mean-square deviation between final simulated heads and measured heads

[NA, not applicable]

\begin{tabular}{clccc}
\hline Layers & \multicolumn{1}{c}{ Water-bearing unit } & $\begin{array}{c}\text { Number of cells with } \\
\text { measured heads }\end{array}$ & $\begin{array}{c}\text { Root-mean-square } \\
\text { deviation } \\
\text { (feet) }\end{array}$ \\
\hline 1 & Bridger aquifer & 41 & 214 \\
2 & Laney aquifer & 69 & 250 \\
3 & New Fork aquifer & 0 & $\mathrm{NA}$ \\
$2-4$ & Wasatch zone of the Wasatch-Fort Union aquifer & 48 & 244 \\
5 & Fort Union zone of the Wasatch-Fort Union aquifer & 42 & 232 \\
\hline
\end{tabular}

Table 6. Root-mean-square deviation between final simulated heads and measured or interpolated heads

\begin{tabular}{clcc}
\hline Layers & \multicolumn{1}{c}{ Wster-bearing unit } & $\begin{array}{c}\text { Numbar of cells with } \\
\text { measured or } \\
\text { interpolated heads }\end{array}$ & $\begin{array}{c}\text { Root-mean-square } \\
\text { devlation } \\
\text { (feet) }\end{array}$ \\
\hline 1 & Bridger aquifer & 239 & 211 \\
2 & Laney aquifer & 896 & 266 \\
3 & New Fork aquifer & 896 & 231 \\
4 & Wasatch zone of the Wasatch-Fort Union aquifer & 1,010 & 143 \\
5 & Fort Union zone of the Wasatch-Fort Union aquifer & 1,010 & 164 \\
\hline
\end{tabular}

\section{Hydraulic Conductivity}

Published estimates of hydraulic conductivity were of limited use in analysis of the Green River Basin because values could not be correlated areally or spatially. Therefore, the flow model was developed to provide an estimate of effective basin values of hydraulic conductivity. Calibrated hydraulic conductivity for subareas in each layer of the flow model is shown in figure 24. Ranges of vertical and horizontal hydraulic conductivity for each aquifer or aquifer zone from the flow-model simulation are listed in table 7. Simulated horizontal and vertical hydraulic conductivity were less than $18 \mathrm{ft} / \mathrm{d}$; whereas measured horizontal hydraulic conductivity equalled or exceeded $420 \mathrm{ft} / \mathrm{d}$, except for the New Fork aquifer. No vertical hydraulic conductivity was measured; the large modeled value in the Laney aquifer is suspect but could reflect local fracturing. Even so, estimates obtained by model analysis generally are within the range of values obtained from aquifer tests and drill-stem tests (table 1). Local variations in sandstone content or fracture density can result in point estimate values of hydraulic conductivity that are significantly different from those obtained by a basin flow-model simulation.

\section{Sensitivity Analysis}

Sensitivity analysis of the flow model was conducted in two parts: observation of hydraulic head and stream-aquifer leakage due to (1) trial-and-error changes in hydraulic conductivity during the calibration procedure, and (2) systematic changes in hydraulic conductivity following calibration.

The first part of the sensitivity analysis consisted of qualitative observations of the effect on the hydraulichead distribution and stream-aquifer leakage caused by changes in hydraulic conductivity between simulations during model calibration. During calibration of the flow model, changes in only one or two subareas were made between each simulation run. Generally, only horizontal or only vertical hydraulic conductivity was changed; sometimes both were changed. Hydraulic conductivity was changed less than an order of magnitude between simulations. Qualitative analysis of head changes between simulations indicated that small changes in hydraulic conductivity made in one or two subareas of a layer generally did not have a substantial effect on the RMS deviation of the entire layer. Cali- 


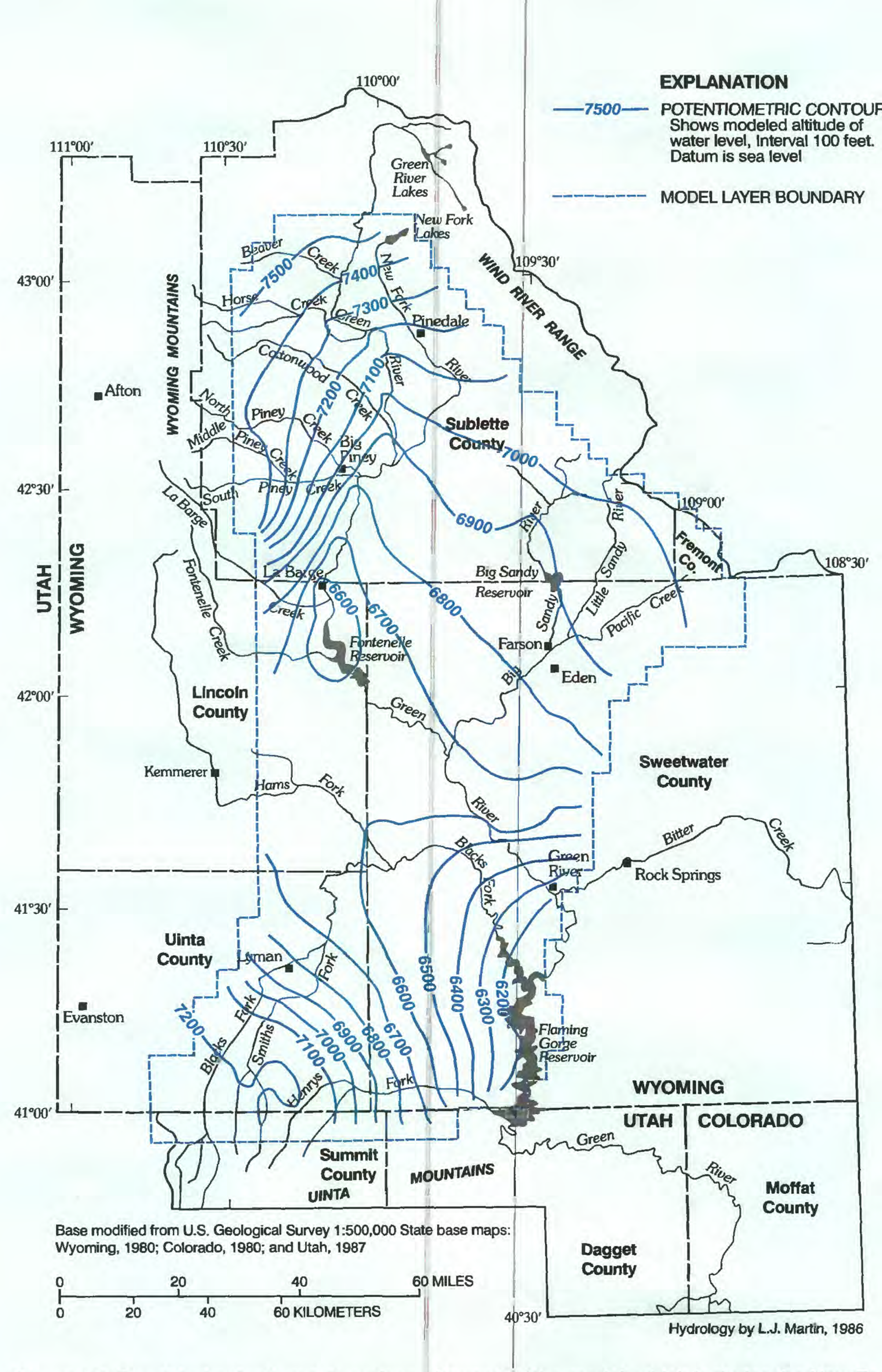

Figure 22. Simulated potentiometric surface of layer 3 of the model, which includes the New Fork aquifer, in the Green River Structural Basin. 

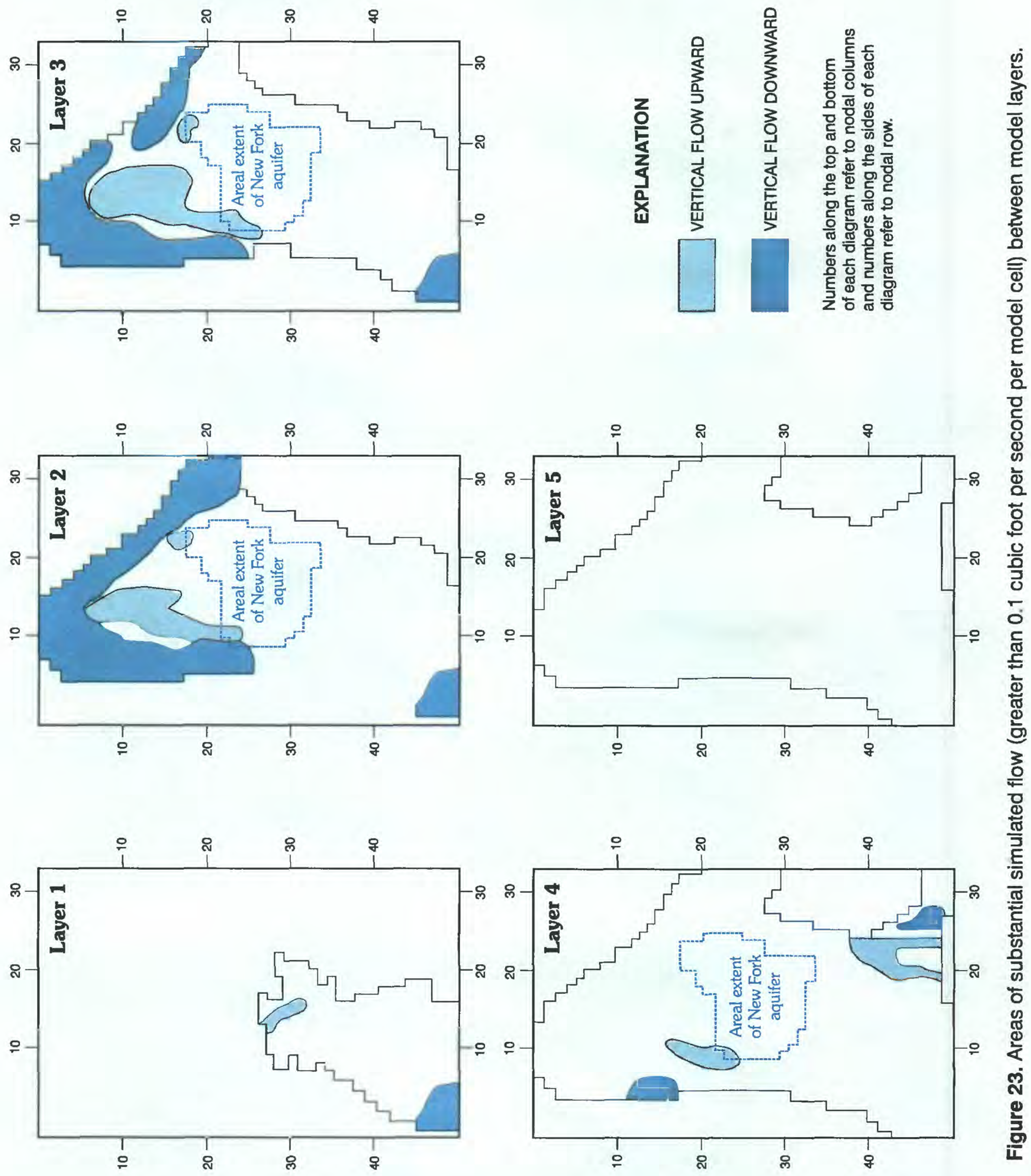


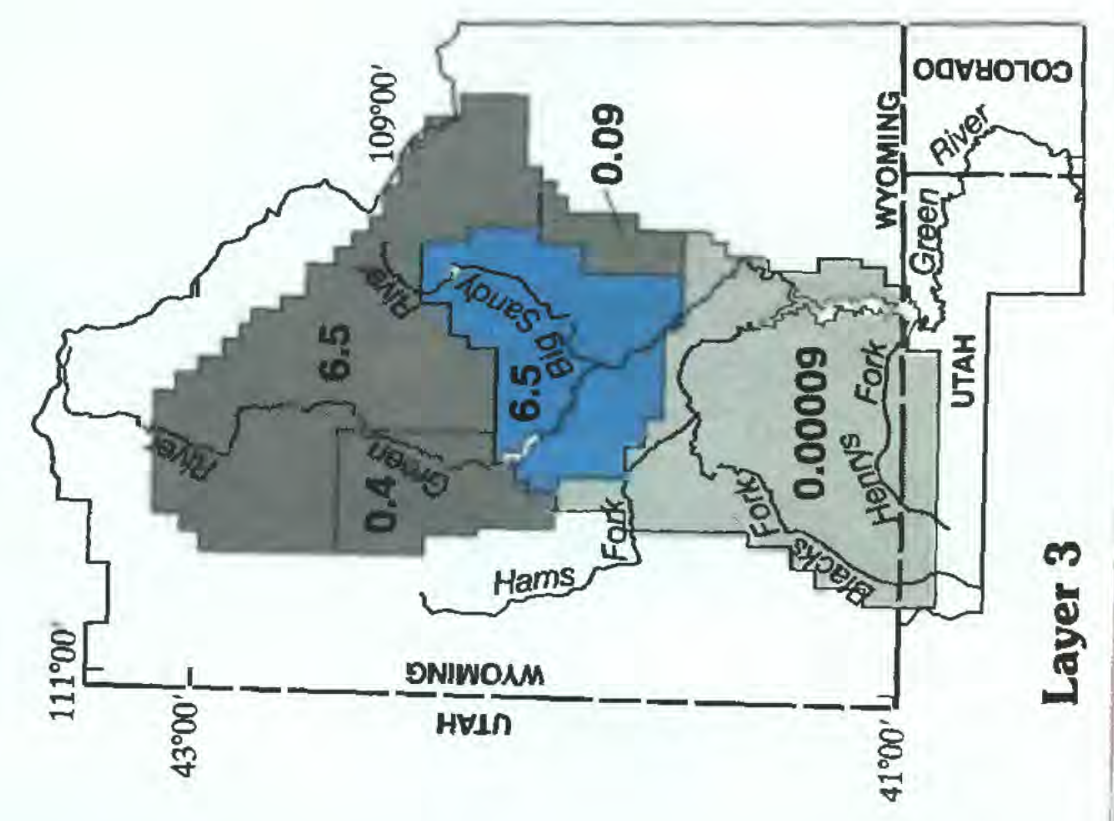

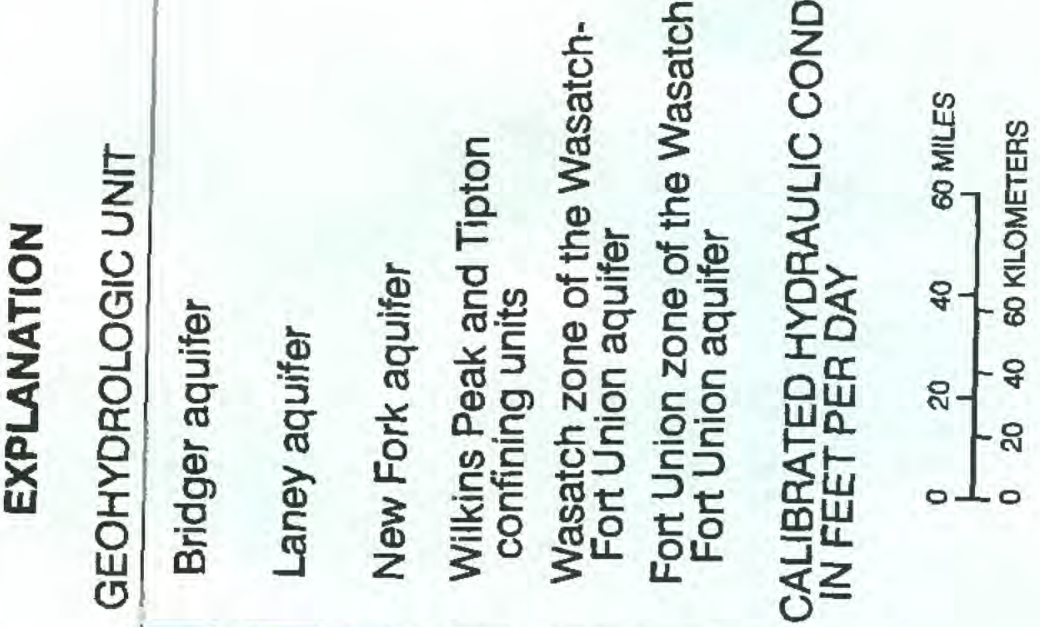
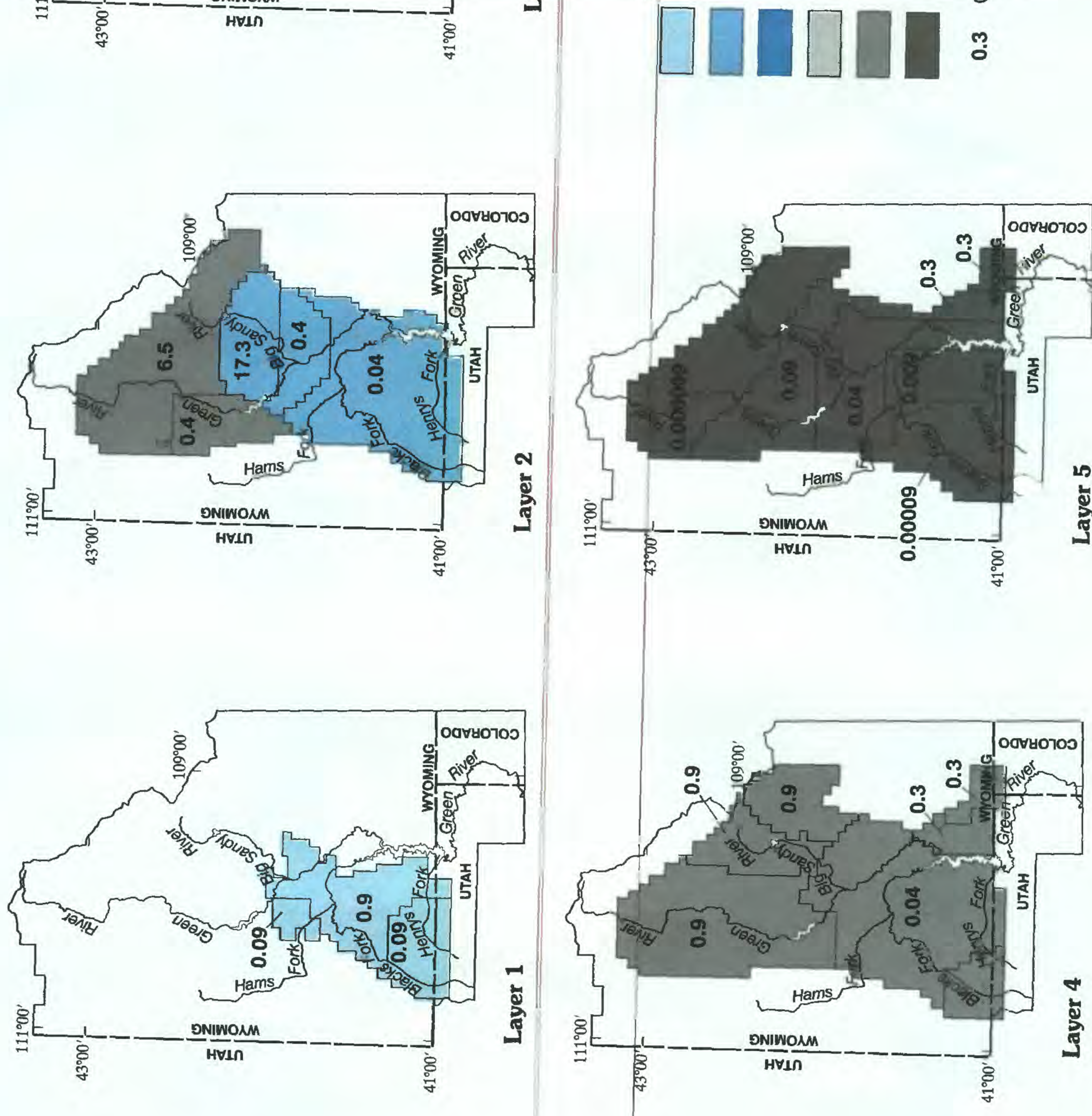

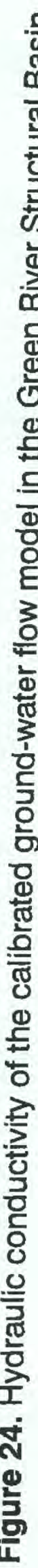


Table 7. Summary of hydraulic conductivity estimates from the ground-water flow model

$[--$, no data $]$

\begin{tabular}{|c|c|c|c|}
\hline \multirow[b]{3}{*}{ Geohydrologic unit } & \multicolumn{3}{|c|}{ Range of hydraulic conductivity, in feet per day } \\
\hline & \multicolumn{2}{|c|}{ Simulated } & \multirow{2}{*}{$\begin{array}{l}\text { Measured } \\
\text { Horizontal }\end{array}$} \\
\hline & Vertical & Horizontal & \\
\hline Bridger aquifer & 0.00001 & $0.09-0.9$ & $0.03-420$ \\
\hline Laney aquifer & $.00001-17.3$ & $.04-17.3$ & $2-1,400$ \\
\hline Wilkins Peak and Tipton confining units ${ }^{1}$ & .00001 & .00009 & -- \\
\hline New Fork aquifer & .1 & 6.5 & $.2-2.0$ \\
\hline Wasatch zone of the Wasatch-Fort Union aquifer & $.001-4$ & $.04-6.5$ & $.03-2,100$ \\
\hline Fort Union zone of the Wasatch-Fort Union aquifer & $.00001-.01$ & $.00001-.3$ & $.02-1,100$ \\
\hline
\end{tabular}

${ }^{1}$ These values were used in the part of the confining bed modeled as a layer.

bration was continued until the simulated stream-aquifer leakage was approximately equal to the estimated stream-aquifer leakage. As stated above, additional simulations achieved a better match between the simulated and measured heads, but resulted in a poorer match between simulated and estimated stream-aquifer leakage.

The second part of the sensitivity analysis consisted of systematically changing the input calibrated hydraulic conductivity to determine the effect on the output of simulated hydraulic heads and output simulated stream-aquifer leakage. Hydraulic conductivities were first increased and then decreased by 50 percent. Simulation model runs were made in which first, horizontal hydraulic conductivity; second, vertical hydraulic conductivity; and third, both horizontal and vertical hydraulic conductivity were changed. Results of the second part of the sensitivity analysis in terms of the RMS deviation in hydraulic head by layer are listed in table 8. Results of the second part of the sensitivity analysis in terms of ground-water discharge to streams are listed in table 9.

Although the total ground-water discharge to stream reaches was not greatly affected by changing hydraulic conductivities (table 9), recharge to or discharge from individual cells along the streams was affected. Generally, simulations in which vertical hydraulic conductivity was increased displayed individual cells in which large quantities of water were recharged to the aquifer or aquifer zone and also cells in which large quantities of water were discharged to the stream. This sensitivity could not be evaluated during calibration because recharge and discharge along parts of the different stream reaches were not individually measured.

The hydraulic conductivity of the calibrated model is a result of an approximate balance between simulated and interpolated heads and simulated and estimated stream-aquifer leakage that are in reasonable agreement. The calibrated simulation has a reasonable match to water-level data throughout the modeled area. However, matching a potentiometric surface does not yield a unique areal distribution of ground-water flow. Either areal hydraulic conductivity distribution or recharge should be known in more detail to lessen the uncertainty. In this case, both factors contain a considerable degree of uncertainty.

\section{Use and Limitations of the Model}

The model was used to estimate values of effective basin hydraulic conductivity in the four aquifers simulated. Calibration of the flow model produced a reasonable, but not necessarily unique, distribution of hydraulic conductivities. Simulated values generally were within the range of values estimated from aquifertest data. Effective basin values of hydraulic conductivity were not necessarily the same as those for local ground-water systems because the simulated basin flow system was at a larger geographic scale and might not have been sensitive to changes of hydraulic conductivity in areas dominated by local ground-water systems. For example, large local variations in aquifer or aquifer zone properties were diminished in the basin model because the aquifer or aquifer zone properties are averaged over the larger area represented by the model cells. 
Table 8. Effects of changing the calibrated hydraulic conductivity on simulated hydraulic heads as indicated by the root-mean-square deviation

\begin{tabular}{|c|c|c|c|c|c|c|c|}
\hline \multirow[b]{2}{*}{ Layer } & \multicolumn{7}{|c|}{$\begin{array}{l}\text { Root-mean-square hydraulic-head deviation, in feet, for indicated } \\
\text { multiple of horizontal (Kh) and vertical (Kv) hydraulic conductivity }\end{array}$} \\
\hline & $\begin{array}{l}\text { Calibrated } \\
\text { Kh and Kv }\end{array}$ & $0.5 \mathrm{Kh}$ & $0.5 \mathrm{Kv}$ & $\begin{array}{c}0.5 \mathrm{Kh} \\
\text { and } \\
0.5 \mathrm{Kv}\end{array}$ & $1.5 \mathrm{Kh}$ & $1.5 \mathrm{Kv}$ & $\begin{array}{c}1.5 \mathrm{Kh} \\
\text { and } \\
1.5 \mathrm{Kv}\end{array}$ \\
\hline 1 & 212 & 312 & 215 & 386 & 254 & 215 & 262 \\
\hline 2 & 266 & 394 & 286 & 446 & 228 & 259 & 224 \\
\hline 3 & 231 & 314 & 228 & 313 & 220 & 233 & 221 \\
\hline 4 & 143 & 288 & 129 & 278 & 145 & 154 & 151 \\
\hline 5 & 164 & 173 & 174 & 274 & 185 & 161 & 178 \\
\hline All & 205 & 318 & 212 & 335 & 199 & 205 & 199 \\
\hline
\end{tabular}

Table 9. Effects of changing calibrated hydraulic conductivity on ground-water discharge to streams

\begin{tabular}{|c|c|c|c|c|c|c|c|c|}
\hline \multirow[b]{2}{*}{ Stream reach } & \multirow{2}{*}{$\begin{array}{l}\text { Estimated } \\
\text { ground- } \\
\text { water } \\
\text { discharge } \\
\text { (cubic feet } \\
\text { per second) } \\
\end{array}$} & \multicolumn{7}{|c|}{$\begin{array}{l}\text { Ground-water discharge, in cubic feet per second, for indicated multiple of horizontal } \\
(\mathrm{Kh}) \text { and vertical (Kv) hydraulic conductivity }\end{array}$} \\
\hline & & $\begin{array}{l}\text { Calibrated } \\
\text { Kh and Kv }\end{array}$ & $0.5 \mathrm{Kh}$ & $0.5 \mathrm{Kv}$ & $\begin{array}{c}0.5 \mathrm{Kh} \\
\text { and } \\
0.5 \mathrm{KV}\end{array}$ & $1.5 \mathrm{Kh}$ & $1.5 \mathrm{Kv}$ & $\begin{array}{l}1.5 \mathrm{Kh} \\
\text { and } \\
1.5 \mathrm{Kv}\end{array}$ \\
\hline $\begin{array}{l}\text { Green River upstream } \\
\text { from Fontenelle } \\
\text { Reservoir }\end{array}$ & 94 & 98 & 98 & 97 & 98 & 97 & 98 & 98 \\
\hline $\begin{array}{l}\text { Green River between } \\
\text { Fontenelle Reservoir } \\
\text { and the town of Green } \\
\text { River, Wyoming }\end{array}$ & 23 & 23 & 14 & 22 & 13 & 31 & 24 & 33 \\
\hline $\begin{array}{l}\text { Green River downstream } \\
\text { from the town of } \\
\text { Green River, Wyoming } \\
\text { including Flaming } \\
\text { Gorge Reservoir }\end{array}$ & 13 & 14 & 13 & 14 & 13 & 16 & 15 & 16 \\
\hline Big Sandy River & 17 & 12 & 22 & 14 & 23 & 3 & 11 & 2 \\
\hline $\begin{array}{l}\text { Henrys Fork, Blacks } \\
\text { Fork, Smiths Fork, } \\
\text { and Hams Fork }\end{array}$ & 7 & 9 & 9 & 9 & 9 & 8 & 9 & 8 \\
\hline
\end{tabular}

${ }^{1}$ Net ground-water discharge to streams after combining ground-water discharge to Henrys Fork and streamflow leakage to aquifers from Blacks Fork, Smiths Fork, and Hams Fork. 
The large node spacing (approximately 3 miles) limits the use of this flow model to basin-wide studies. Even so, knowledge about the ground-water-flow system gained from this basin-wide study should be beneficial if used as the basis for more detailed studies of local areas in the Green River Basin. Information obtained about recharge, discharge, and movement between aquifers and aquifer zones will be useful as a basis in planning future local studies. Finally, head distributions derived from this model should be useful as boundary information for future smaller area models in the Green River Basin.

\section{SUMMARY}

The ground-water system in the Tertiary rocks of the Green River Structural Basin was studied as part of the Regional Aquifer System Analysis program of the U.S. Geological Survey. The purpose of the study was to classify and map basin aquifers, describe hydrologic and geochemical characteristics of flow, and quantitatively analyze basin flow systems under steady-state conditions. Accomplishing such a purpose was completed by quantifying and analyzing the geology and geohydrology of the area and by simulating the ground-water flow with a steady-state computer model.

The Bridger Formation is an aquifer in the southern part of the Green River Basin. Hydraulic conductivity is smaller in nonfractured parts of the Bridger aquifer where the ground-water resource has not been developed. Flow-model estimates of Bridger aquifer hydraulic conductivity range from 0.09 to 0.9 feet per day. Ground-water movement in the Bridger aquifer primarily is horizontal. Significant vertical leakage into deeper aquifers occurs only along the Uinta Mountain front where the underlying Green River Formation is conglomeratic. Ground water in the Bridger aquifer flows from recharge areas along the Uinta Mountains to the north and northeast and discharges to Smiths Fork, Blacks Fork, and the Green River.

The Laney Member of the Green River Formation is classified as an aquifer in this report but acts as a confining unit where buried by the Bridger aquifer. Fractures and solution channels near the Big Sandy River make the Laney Member a highly productive aquifer in that area. Hydraulic conductivity in the fractured part of the aquifer is estimated to be about 17.3 feet per day. Estimates of Laney aquifer hydraulic conductivity from the calibrated flow model range from 0.04 to 0.4 feet per day where the Laney is not fractured and acts as a confining unit. Most ground water that enters the Laney aquifer is derived from upward leakage from the New Fork aquifer in the central part of the Green River Basin and from irrigation recharge in the Farson-Eden, Wyoming area. Virtually no water leaks upward to the Laney aquifer in areas underlain by bedded trona deposits of the Wilkins Peak confining unit. Most discharge from the Laney aquifer is along the Big Sandy River and the Green River between Fontenelle and Flaming Gorge Reservoirs.

The Wilkins Peak Member of the Green River Formation is a significant basin confining unit. Bedded trona deposits in the southern half of the Green River Basin prevent vertical movement of water through the Wilkins Peak confining unit.

The New Fork Tongue of the Wasatch Formation is a sandstone aquifer located in the northern part of the Green River Basin between the Wilkins Peak and Tipton Shale Members of the Green River Formation. The New Fork aquifer thins to the south and is absent near the town of Green River, Wyoming. Ground water enters the New Fork aquifer from recharge areas adjacent to the Wind River Range and by upward leakage through the Tipton Shale from the underlying Wasatch aquifer. Water in the New Fork aquifer moves in a southerly direction and discharges by upward leakage to the Laney aquifer. Hydraulic conductivity of the New Fork aquifer was estimated from the calibrated simulation model to be 6.5 feet per day.

The Tipton Shale Member of the Green River Formation forms a relatively thin confining unit between the New Fork aquifer, above, and the Wasatch zone of the Wasatch-Fort Union aquifer, below. In the southern Green River Basin, where the New Fork aquifer is absent, the Tipton Shale confining unit is vertically contiguous with the underlying Wilkins Peak confining unit.

The main body of the Wasatch Formation is a thick sequence of fluvial sandy shale and siltstone with varying amounts of sandstone. There are extensive areas where thick permeable sandstones are at or near land surface in the northern Green River Basin. The amount of sandstone generally decreases, resulting in less permeable rocks in the southern part of the Green River Basin, where the Wasatch is buried under the Bridger and Green River Formations. Hydraulic conductivity in the Wasatch zone of the Wasatch-Fort Union aquifer ranges from 0.04 to 6.5 feet per day, as estimated by the calibrated model.

Ground water in the Wasatch zone follows short, long, and basin flow paths. Short flow paths are the shallow flow paths where the Wasatch zone is at land surface along ihe basin margins. Long flow paths occur from recharge areas adjacent to the Wind River Range and the Overthrust Belt to discharge areas along the Green and New Fork Rivers in the northern Green 
River Basin. Basin ground-water flow paths occur in deep parts of the Wasatch zone and where the Wasatch is overlain by the Tipton Shale confining unit. Generally, water percolates downward from shallow parts of the Wasatch zone in the northern part of the basin and flows horizontally toward the south. Flaming Gorge is the principal discharge area for water following basin flow paths.

The Fort Union Formation is lithologically similar to the Wasatch Formation and consists of fluvial sandstones and siltstones. The Fort Union zone of the Wasatch-Fort Union aquifer is less permeable than the overlying Wasatch zone because it is located at greater depth and stratigraphically beneath the Wasatch zone. Hydraulic conductivity values in the Fort Union zone of the Wasatch-Fort Union aquifer range from 0.00001 to 0.3 feet per day, as estimated by the calibrated model.

Ground-water movement in the Fort Union zone is similar to movement in the overlying Wasatch zone. Recharge occurs around the basin margins from infiltration of precipitation and as downward leakage from the overlying Wasatch zone. Water moves along short, long, and basin flow paths toward the center of the basin where it is discharged by upward leakage into the overlying Wasatch zone in the southern part of the basin.

Recharge to aquifers in the Green River Basin occurs primarily in outcrop areas by infiltration of precipitation and infiltration of snowmelt runoff from adjacent mountain ranges. Very little recharge occurs in the central part of the basin because of smaller amounts of precipitation at the lower elevations and large evapotranspiration rates. Infiltration of excess irrigation water in the Farson-Eden, Wyoming area is an additional source of recharge. Total ground-water recharge is estimated to be about 165 cubic feet per second.

Streams are major areas of basin ground-water discharge for aquifers in Tertiary rocks in the Green River Basin. Base-flow statistics for stream-gaging stations and flow-model analysis were used to quantify discharge. Net ground-water discharge to streams is estimated to be about 163 cubic feet per second.

A computer model was developed to simulate steady-state ground-water flow in the aquifers in Tertiary rocks of the Green River Basin. Basin geohydrologic characteristics of the aquifers in Tertiary rocks are described by the calibrated flow model. Values for aquifer properties were adjusted using a trial-and-error process until an acceptable match was obtained between the measured and simulated hydraulic heads and between the measured and simulated stream-aquifer water budgets in the five layers of the model. The flow model was used to refine the conceptual model of ground-water recharge and to estimate effective basin values of hydraulic conductivity.

\section{SELECTED REFERENCES}

Ahern, John, Collentine, Michael, Cooke, Steve, 1981, Occurrence and characteristics of ground water in the Green River Basin and Overthrust Belt, Wyoming: Water Resources Research Institute, University of Wyoming, $2 \mathrm{v}$.

Barker, D.A., and Sapik, D.B., 1965, An investigation of ground water as a source of irrigation supply, Eden Project, Wyoming: U.S. Department of Interior, Bureau of Reclamation, Region 4, Salt Lake City, Utah, $51 \mathrm{p}$.

Bradley, W.H., 1964, Geology of Green River Formation and associated Eocene rocks in southwestern Wyoming and adjacent parts of Colorado and Utah: U.S. Geological Survey Professional Paper 496-A, 86 p.

Bradley, W.H., and Eugster, H.P., 1969, Geochemistry and paleolimnology of the trona deposits and associated authigenic minerals of the Green River Formation of Wyoming: U.S. Geological Survey Professional Paper 496-B, $71 \mathrm{p}$.

Dana, G.F., 1962, Ground water reconnaissance study of the State of Wyoming, Part 4, Green River Basin: Wyoming Natural Resources Board, 9 p.

Dana, G.F., and Smith, J.W., 1973, Artesian aquifer, New Fork Tongue of the Wasatch Formation, northern Green River Basin, in Wyoming Geological Association Guidebook, 25th Annual Field Conference, Symposium and core seminar on the geology and mineral resources of the greater Green River Basin, Casper, Wyoming, 1973: p. 201-206.

Eakin, T.E., and others, 1951, Contributions to the hydrology of eastern Nevada: Nevada State Engineer Water Resources Bull. 12.

Freethy, G.W., Kimball, B.A., Wilberg, D.E., and Hood, J.W., 1988, General hydrogeology of the aquifers of Mesozoic age, Upper Colorado River Basin--excluding the San Juan Basin--Colorado, Utah, Wyoming, and Arizona: U.S. Geological Survey Hydrologic Investigations Atlas HA-698, 2 sheets.

Freethey, G.W., and Cordy, G.E., 1991, Geohydrology of Mesozoic rocks in the Upper Colorado River Basin in Arizona, Colorado, New Mexico, Utah, and Wyoming, excluding the San Juan Basin: U.S. Geological Survey Professional Paper 1411-C, 118 p. 
Glover, K.C., 1983, Digital model of the Bates Creek alluvial aquifer near Casper, Wyoming: U.S. Geological Survey Water-Resources Investigations Report $82-4068,45$ p.

1986, Leachate migration from an in situ oil-shale retort near Rock Springs, Wyoming: U.S. Geological Survey Open-File Report 85-575, 68 p.

1990, Stream-aquifer system in the Upper Bear River Valley, Wyoming: U.S. Geological Survey WaterResources Investigations Report 89-4173, 51 p.

Gordon, E.D., King, N.J., Haynes, G.L., Jr., and Cummings, T.R., 1960, Occurrence and quality of water in the northern Bridger Basin and adjacent Overthrust Belt, Wyoming, in Wyoming Geological Association Guidebook, 15th Annual Field Conference, Overthrust Belt of southwestern Wyoming and adjacent areas: p. 227247.

Hood, J.W., and Waddel, K.M., 1968, Hydrologic reconnaissance of Shell Valley, Tooele County, Utah: Utah State Engineer Tech. Pub. 18.

Love, J.D., 1961, Definition of Green River, Great Divide, and Washakie Basins, southwestern Wyoming: American Association of Petroleum Geologists Bulletin, v. 45 , no. 10 , p. $1,749-1,755$.

Love, J.D., and Christiansen, A.C., 1985, Geologic map of Wyoming: U.S. Geological Survey map, scale 1:500,000, 1 sheet.

Love, J.D., Christiansen, A.C., and Ver Ploeg, A.J., comps., 1992, Second draft of a stratigraphic chart showing Phanerozoic nomenclature for the state of Wyoming: Geological Survey of Wyoming, Open-File Report 92-20.

Lowham, H.W., and others, 1985, Hydrology of Area 52, Rocky Mountains coal province, Wyoming, Colorado, Idaho, and Utah: U.S. Geological Survey WaterResources Investigations Report 83-761, 96 p.

McDonald, M.G., and Harbaugh, A.W., 1988, A modular three-dimensional finite-difference ground-water flow model: U.S. Geological Survey Techniques of WaterResources Investigations, Book 6, Chapter A1, 576 p.

Price, Don, and Miller, L.L., 1975, Hydrologic reconnaissance of the southern Uinta Basin, Utah and Colorado: Utah Department of Natural Resources Technical Publication $49,66 \mathrm{p}$.

Robinove, C.J., and Cummings, T.R., 1963, Ground-water resources and geology of the Lyman-Mountainview area, Uinta County, Wyoming: U.S. Geological Survey Water-Supply Paper 1669-E, 43 p.
Spearing, E.R., 1969, Stratigraphy and sedimentation of the Paleocene-Eocene Hoback Formation, in Wyoming Geological Association Guidebook, 21st Annual Field Conference, Symposium on Tertiary rocks of Wyoming, Casper, Wyoming, 1969: p. 65-76.

Taylor, O.J., Hood, J.W., and Zimmerman, E.A., 1986, Hydrogeologic framework of the Upper Colorado River Basin--excluding the San Juan basin--Colorado, Utah, Wyoming, and Arizona: U.S. Geological Survey Hydrologic Atlas HA-687, 2 sheets.

Teller, R.W., and Chafin, D.T., 1986, Selected drill-stem test data for the Upper Colorado River Basin: U.S. Geological Survey Water-Resources Investigations Report 84-4146.

Trescott, P.C., 1975, Documentation of finite-difference model for simulation of three-dimensional groundwater flow: U.S. Geological Survey Open-File Report 75-438, $103 \mathrm{p}$.

Trescott, P.C., Pinder, G.F., and Larson, S.P., 1976, Finitedifference model for aquifer simulation in two dimensions with results of numerical experiments: U.S. Geological Survey Techniques of Water-Resources Investigations, Book 7, Chapter C1, $116 \mathrm{p}$.

U.S. Geological Survey, 1974, Hydrologic unit map-1974, State of Wyoming: U.S. Geological Survey, scale 1:500,000.

Welder, G.E., 1968, Ground-water reconnaissance of the Green River Basin, southwestern Wyoming: U.S. Geological Survey Hydrologic Investigations Atlas HA-290, 3 sheets.

Zimmerman, E.A., and Collier, K.R., 1985, Ground-water data, Green River Basin, Wyoming: U.S. Geological Survey Open-File Report 83-943, 511 p. 